\title{
Miocene syn-rift evolution of the North Croatian Basin (Carpathian-Pannonian Region): new constraints from Mts. Kalnik and Požeška gora volcaniclastic record with regional implications
}

\author{
Mihovil Brlek ${ }^{1}$ - Steffen Kutterolf ${ }^{2} \cdot$ Sean Gaynor ${ }^{3} \cdot$ Klaudia Kuiper $^{4} \cdot$ Mirko Belak $^{1} \cdot$ Vlatko Brčić $^{1}$. \\ Katarína Holcová ${ }^{5} \cdot K_{\text {Ko-Lung Wang }}^{6,7} \cdot$ Koraljka Bakrač $^{1} \cdot$ Valentina Hajek-Tadesse $^{1} \cdot$ Ivan Mišur $^{1} \cdot$ Marija Horvat $^{1}$. \\ Sanja Šuica ${ }^{8}$. Urs Schaltegger ${ }^{3}$
}

Received: 12 May 2020 / Accepted: 19 August 2020

(c) Geologische Vereinigung e.V. (GV) 2020

\begin{abstract}
Mts. Kalnik and Požeška gora volcaniclastic sequences hold valuable information concerning the Miocene syn-rift evolution of the North Croatian Basin, and the evolution of the Carpathian-Pannonian Region and the Central Paratethys. We present volcanological, high-precision geochronological, and compositional data of volcanic glass to constrain their tephrochronology, magmatic provenance, and timing of the initial Central Paratethys flooding of the North Croatian Basin. Based on CA-ID-TIMS U-Pb zircon ages (18.060 $\pm 0.023 \mathrm{Ma}$ for Mt. Kalnik and 15.345 $\pm 0.020 \mathrm{Ma}$ for Mt. Požeška gora) and coeval ${ }^{40} \mathrm{Ar} /{ }^{39} \mathrm{Ar}$ sanidine ages $(18.14 \pm 0.38 \mathrm{Ma}$ and $18.25 \pm 0.38 \mathrm{Ma}$ for Mt. Kalnik and $15.34 \pm 0.32 \mathrm{Ma}$ and $15.43 \pm 0.32 \mathrm{Ma}$ for Mt. Požeška gora), Mt. Kalnik rhyolitic massive ignimbrites and Mt. Požeška gora rhyolitic primary volcaniclastic turbidites are coeval with Carpathian-Pannonian Region Miocene post-collisional silicic volcanism, which was caused by lithospheric thinning of the Pannonian Basin. Their affiliation to Carpathian-Pannonian Region magmatic activity is supported by their subduction-related geochemical signatures. Although Mts. Kalnik and Požeška gora volcaniclastics are coeval with the Bükkalja Volcanic Field Csv-2 rhyolitic ignimbrites, North Alpine Foreland Basin, Styrian Basin, Vienna Basin, and Dinaride Lake System bentonites and volcaniclastic deposits, reliable tephrochronological interpretations based on comparison of volcanic glass geochemical composition are not possible due to a lack of data and/or methodological discrepancies. Our new high-precision geochronology data prove that the initial Middle Miocene (Badenian) marine flooding of parts of the North Croatian Basin occurred at least $\sim 0.35 \mathrm{Ma}$ (during the NN4 Zone) before the generally accepted $\sim 15$ Ma maximum flooding age at the basin scale, calibrating the timing of the onset of the widespread "mid-Langhian" Central Paratethys flooding.
\end{abstract}

Keywords Miocene $\cdot$ North Croatian Basin volcaniclastic rocks $\cdot$ High-precision geochronology $\cdot$ Tephrochronology Carpathian-Pannonian region · Central Paratethys

\section{Introduction}

The Pannonian Basin (PB), as part of the Carpathian-Pannonian region (CPR; part of the long-lived Alpine-Carpathian-Dinaridic orogenic system; Schmid et al. 2008; Handy et al. 2014), represents a back-arc basin formed due

Electronic supplementary material The online version of this article (https://doi.org/10.1007/s00531-020-01927-4) contains supplementary material, which is available to authorized users.

Mihovil Brlek

mihovil.brlek@hgi-cgs.hr

Extended author information available on the last page of the article to Oligocene-Miocene subduction roll-back in the Carpathians and Dinarides (Horváth et al. 2006, 2015; Balázs et al. 2016). Time and space complexity of geological evolution of the area and adjacent regions is reflected in the Early-Middle Miocene CPR-related magmatic activity (Pécskay et al. 2006; Seghedi and Downes 2011; Lukács et al. 2015, 2018), as well as in the Central Paratethys (CP) transgressions and open sea connections into the Mediterranean (Sant et al. 2017; Kováč et al. 2018). However, some of the regional (CPR and CP related) and especially local (North Croatian Basin, NCB related; Pavelić and Kovačić 2018) issues remain unresolved and/or are a matter of debate. There are several unresolved topics which could help inform the Miocene NCB syn-rift evolution, including: 
(1) tephrochronology, volcanic provenance and petrogenesis, as well as geodynamic setting of NCB volcaniclastic and volcanic rocks (e.g., Pamić and Balen 2001a; Pécskay et al. 2006; Seghedi and Downes 2011; Mandic et al. 2012; Lukács et al. 2018), and (2) timing of the initial Miocene CP flooding of the NCB (Brlek et al. 2018; Pavelić and Kovačić 2018; Mandic et al. 2019a). The Lower-Middle Miocene Mts. Kalnik and Požeška gora volcaniclastic and sedimentary deposits represent an outstanding sedimentary record for multi-proxy high-resolution integrated studies to better understand these topics.

Therefore, by conducting volcanological and sedimentological determinations, integrated high-precision $\mathrm{U}-\mathrm{Pb}$ and $\mathrm{Ar} / \mathrm{Ar}$ radiometric dating (EARTHTIME initiative; Schmitz and Kuiper 2013), and geochemical fingerprinting of Mts. Kalnik and Požeška gora volcaniclastic deposits, we will:

(1) help aid in understanding the magmatic provenance, tephrochronology and petrogenetic reconstructions for Early-Middle Miocene magmatism within and surrounding the NCB;

(2) provide high-precision geochronological constraint on the timing of the initial CP flooding of the NCB.

Such valuable new data will also enable more constrained regional CPR- and CP-related reconstructions.

\section{Geological setting and lithostratigraphy}

\section{North Croatian Basin (Carpathian-Pannonian region)}

The Carpathian-Pannonian region, located in the northeastern part of the Alpine-Mediterranean region, in eastern Central Europe, is considered to be a typical Mediterranean area characterized by arcuate, retreating subduction, formation of extensional basins within the orogen, and magmatism during the last $20 \mathrm{Ma}$ (Fig. 1a; Pécskay et al. 2006; Harangi and Lenkey 2007; Seghedi and Downes 2011; Handy et al. 2014; Horváth et al. 2015; Balázs et al. 2016). The Pannonian Basin, within the CPR, represents a back-arc basin formed due to Oligocene-Miocene diachronous extension in the $\mathrm{AlCaPa}$ (derived from the names Alps, Carpathians and Pannonian Basin; accompanied by lateral extrusion from the Eastern Alps) and Tisza-Dacia tectonic mega-units. The extension of these continental units (juxtaposed along MidHungarian Fault Zone), accompanied by translations and opposite sense rotations, was a result of Oligocene-Miocene subduction roll-back in the Carpathians and Dinarides, combined with asthenospheric mantle flow and/or lithospheric delamination (e.g., Horváth et al. 2006, 2015; Matenco and Radivojević 2012; Balázs et al. 2016; Lukács et al. 2018). At the PB margins with the Eastern Alps, Dinarides and Carpathians (as well as in other parts of the PB) the extension took place dominantly along extensional detachments, with Oligocene-Miocene exhumation occurring in the footwall of detachments (Balázs et al. 2016; Fodor et al. 2020 and references therein). Complex post-collisional (sensu Seghedi and Downes 2011) tectonic processes in the CPR generated, together with evolution of magmas in the crustal environment, a Lower Miocene to recent magmatic events with products of highly diverse composition. Overall, CPR magmatic activity shows a distinct migration in time from west to east (Pécskay et al. 2006; Harangi and Lenkey 2007; Seghedi and Downes 2011; Lukács et al. 2015, 2018; Szakács et al. 2018).

The North Croatian Basin (NCB; Fig. 1b; Pavelić and Kovačić 2018) covers almost the entire area of northern Croatia and is situated southeast of the Hrvatsko Zagorje Basin (HZB; Fig. 1b), which was a gulf of Trans-TethyanTrench-Corridor connecting the Paratethys Sea to the Mediterranean Sea from the Oligocene to the Early Miocene (Rögl 1998; Mandic et al. 2012; Pavelić and Kovačić 2018). The NCB, located at the south-western margin of the PB (Fig. 1b; Pavelić and Kovačić 2018), represents a rift-type basin (generated by continental passive rifting) that began foming during the Early Miocene (Pavelić and Kovačić 2018). The extension formed four elongated sub-basins (half-grabens, including the Drava and Sava depressions), that represented the main depocenters (Fig. 1b). The typical sedimentary successions of the initial basal Lower-Middle Miocene (Ottnangian-Lower Badenian according to Pavelić and Kovačić 2018 and references therein) NCB include continental, alluvial and lacustrine (Southern Pannonian Basin Lake System, SPBLS sensu Mandić et al. 2019a) sediments unconformably overlying the strongly tectonized and lithologically heterogeneous pre-Neogene basement (GKRH 2009). The alluvial-lacustrine series of the NCB is generally overlain by Middle Miocene (Badenian) transgressive marine deposits representing a widespread ingression of the Paratethys Sea into the NCB (Ćorić et al. 2009; Mandic et al. 2012, 2019a; Marković 2017; Pavelić and Kovačić 2018). The Ottnangian-Middle Badenian phase of NCB evolution is regarded as syn-rift (Pavelić and Kovačić 2018; see also Balázs et al. 2016). Early-Middle Miocene volcanic activity was also recorded in the NCB in the form of volcanic and volcaniclastic rocks, which are intercalated with penecontemporaneous alluvial, lacustrine and marine sediments (Pamić et al. 1995; Pamić and Balen 2001a; Pécskay et al. 2006; Seghedi and Downes 2011; Mandic et al. 2012; Marković 2017).

\section{Mt. Kalnik}

According to Pavelić and Kovačić (2018), the Mt. Kalnik area marks the tentative boundary between the two basins which evolved in the area of north Croatia during the Early 
Fig. 1 a Geographical position of the North Croatian (NCB) and other basins of the Carpathian-Pannonian region (CPR). The position of the Hrvatsko Zagorje Basin (HZB, not a part of CPR) is also provided. $Z B$ Zala Basin, $S B$ Styrian Basin, $D B$ Danube Basin, $V B$ Vienna Basin, $S O B$ Somogy Basin, $B K B$ Bačka Basin, $B T B$ Banat Basin, $B B$ Bèkès Basin, TRB Transylvanian Basin, $T B$ Transcarpathian Basin, ESB East Slovak Basin. b The position of the Mts. Kalnik (KAL) and Požeška gora (ŠKR) Miocene sections of volcaniclastic rocks studied here. The spreading and representation of pre-Miocene and Miocene deposits in the NCB according to GKRH (2009)
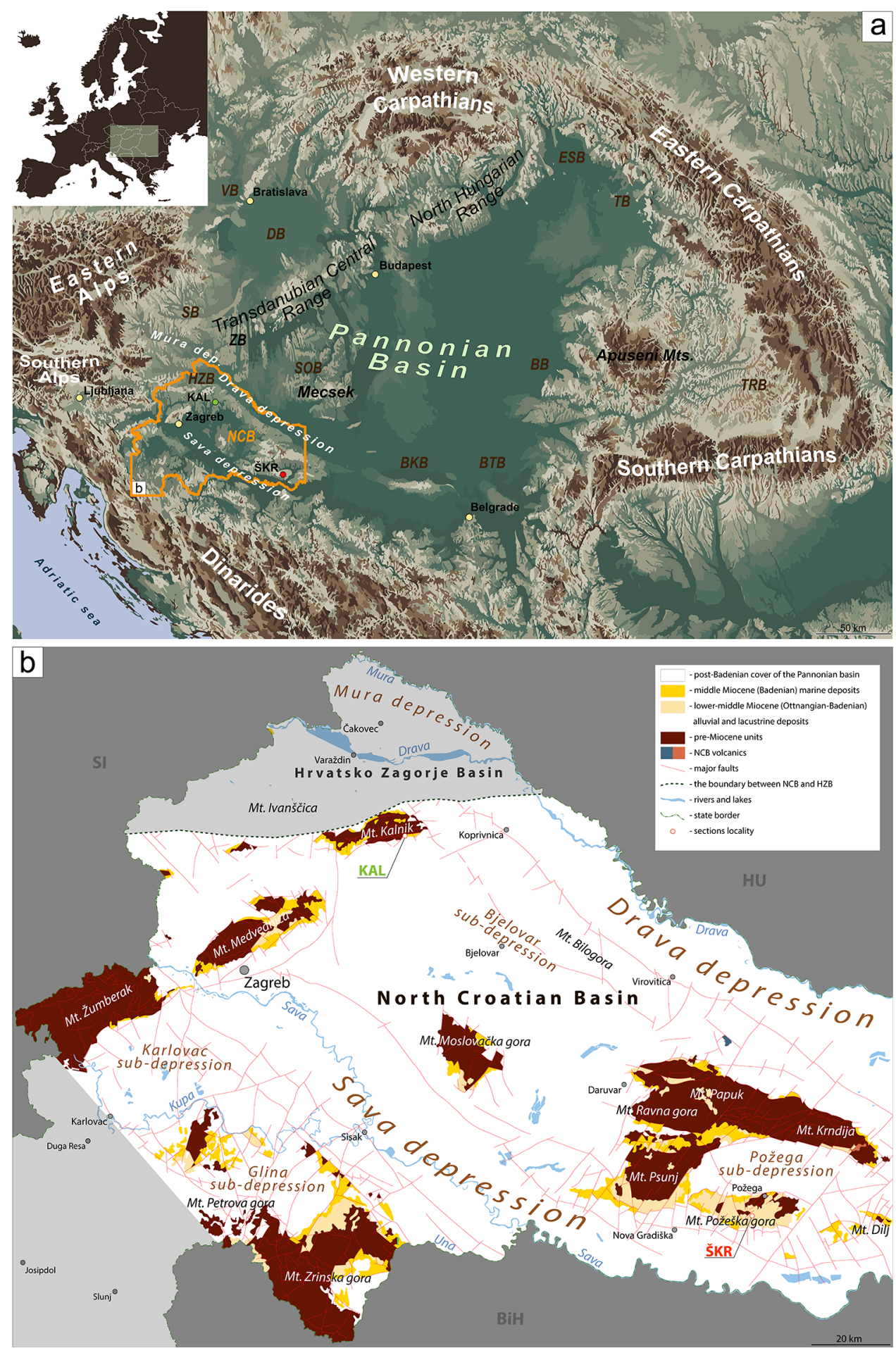

Miocene: NCB and HZB (Fig. 1b), and have different depositional histories. According to Mandic et al. (2012), the HZB tectonostratigraphic unit is represented on Mt. Kalnik by Egerian-Eggenburgian paralic coal-bearing marginal marine and shallow marine deposits. The overlying NCB tectonostratigraphic unit is marked by basal fluvial and lake deposits (Pavelić et al. 2001), which are transgressively overlain by Badenian marine sediments. In the eastern part of Mt. Kalnik, the volcaniclastic deposits $(18.07 \pm 0.07 \mathrm{Ma}$ based on Ar/Ar geochronology; Glogovnica locality; see also Tibljaš et al. 2002) are interpreted to be intercalated with the basal Ottnangian fluvial NCB deposits, representing the base of NCB continental series and therefore constraining the timing of the initial rifting tectonics of the 
NCB (Mandic et al. 2012). However, Šimunić et al. (2013, 2014) ascribed volcaniclastic deposits with associated sediments (varying from fresh water to marine, including coals) from the eastern part of Mt. Kalnik to Lower Miocene (Egerian-Eggenburgian) HZB tectonostratigraphic unit. Mt. Kalnik volcaniclastic rocks have been correlated with the HZB Upper Oligocene-Lower Miocene (Egerian-Eggenburgian) andesites and dacites (as well as pyroclastic rocks) exposed in northern Croatia, and related to the easternmost part of the Periadriatic Fault Zone magmatic activity (Pamić and Balen 2001a, b; Tibljaš et al. 2002; Mandic et al. 2012;
Šimunić et al. 2014). The KAL section volcaniclastics investigated herein are located in the eastern part of Mt. Kalnik (Figs. 2, 3).

\section{Mt. Požeška gora}

Mt. Požeška gora (Fig. 1b) is part of the Slavonian Mts. complex, composed of five hills, up to $1000 \mathrm{~m}$ high, named Mts. Papuk, Krndija, Psunj and Dilj gora (Kovačić and Pavelić 2017). The basement of the Miocene deposits in Mt. Požeška gora consists of Triassic, Upper Cretaceous and Paleogene
Fig. 2 The locations of the KAL and ŠKR sections

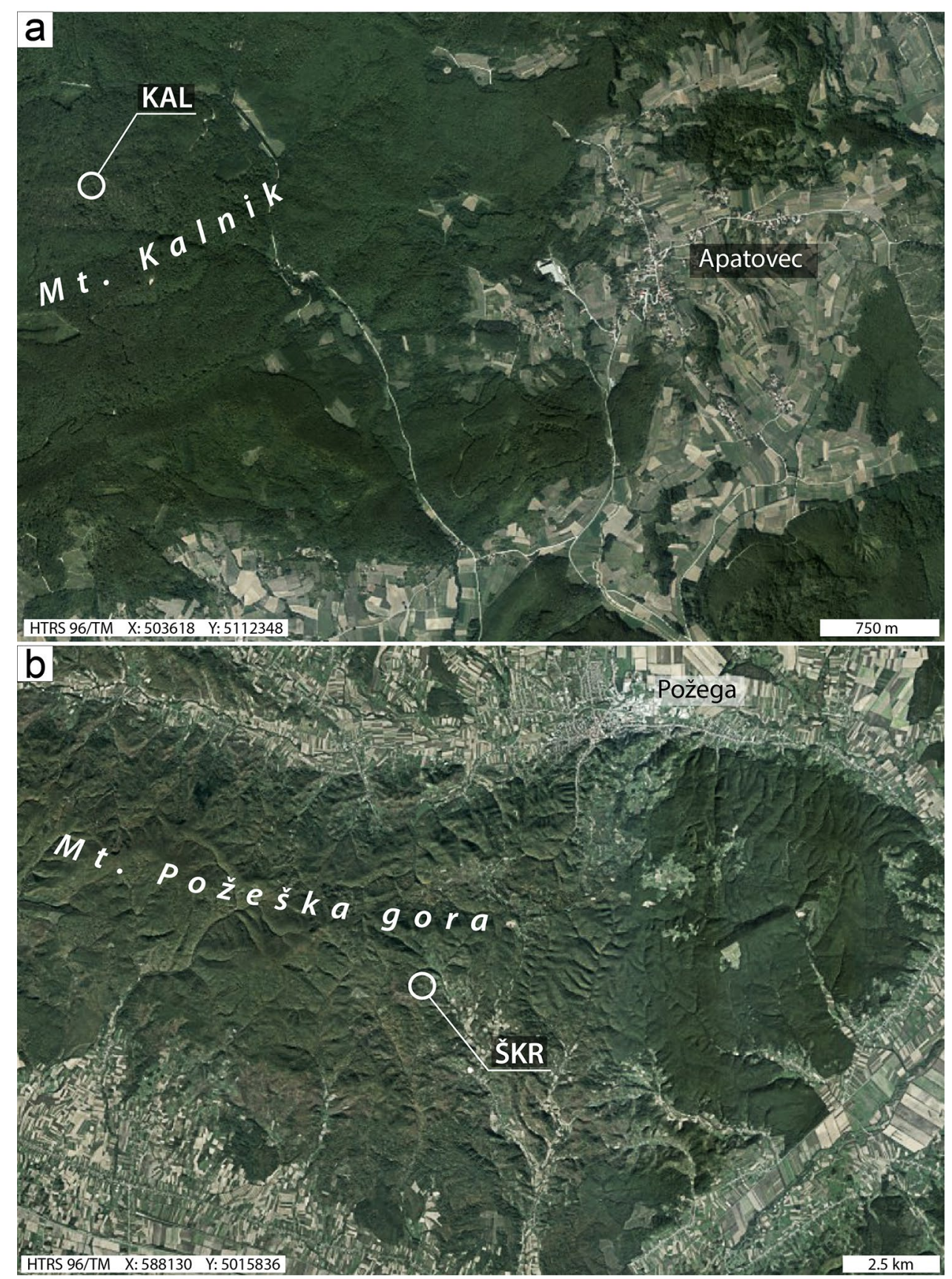


rocks and corresponding formations (Halamić et al. 2019). Due to excellent outcrop conditions of Miocene NCB synrift deposits in Mt. Požeška gora, the continuous transition from the basal Ottnangian-Karpatian alluvial coarse-grained deposits with aeolian siltstones (Daranovac Formation), to SPBLS brackish-lacustrine deposits (Glavnica Formation; Hajek-Tadesse et al. 2009; Ottnangian-Lower Badenian according to Halamić et al. 2019 vs. Lower Badenian according to Kovačić and Pavelić 2017; Mandic et al. 2019a) and Central Paratethys marine deposits (offshore marlsVejalnica Formation with intercalated volcaniclastic rocks of Crnka unit; Karpatian-Badenian according to Halamić et al. 2019 vs. Middle Badenian according to Kovačić and Pavelić 2017; Mandic et al. 2019a) is exposed. The ŠKR section volcaniclastics investigated herein and intercalated with marine sediments are located in the central part of Mt. Požeška gora (Figs. 2, 3).

\section{Materials and methods}

\section{Volcanology and sedimentology}

The classification, description, and interpretation of KAL and ŠKR volcaniclastic deposits and their lithofacies followed the principles reviewed and outlined in Cas and Wright (1988), McPhie et al. (1993), Branney and Kokelaar (2002), White and Houghton (2006), Carey and Schneider (2011), and Brown and Andrews (2015). Special care was also given to investigation of soft sediment deformation structures (SSDS; e.g., Douillet et al. 2015). To discern epiclastic from primary syn-eruptive sedimentation processes, the emphasis was also put on the implications provided by the geochemical composition of volcaniclastic rocks (e.g., Schindlbeck et al. 2013; Lowe et al. 2017). Observations of lateral characteristics ( $>2 \mathrm{~m}$ laterally from the main geological columns) of the analyzed lithofacies were limited due to poor outcrop exposures.

\section{Geochemistry}

The principles of geochemical fingerprinting of Mts. Kalnik and Požeška gora volcaniclastic rocks which enables the most reliable classification (composition of the erupted magma), discrimination (primary vs. secondary volcaniclastics; e.g., Schindlbeck et al. 2013), tephrochronological and volcanic provenance reconstructions (e.g., Kutterolf et al. 2014, 2018; Schindlbeck et al. 2016, 2018; Hopkins and Seward 2019), are reviewed and outlined in Lowe (2011) and Lowe et al. (2017 and references therein) and include EMP and LA-ICP-MS analysis of major and trace element composition of individual volcanic glass shards. Such grainspecific approach has many advantages compared with bulk methods and is essential since bulk samples often show compositional variation with distance from volcanic source and may have incorporated xenocrysts, xenoliths, and detrital contaminants (Lowe et al. 2017).

The Mt. Kalnik tuffs to coarse lapilli tuffs (samples KAL5A, B and KAL-1) and Mt. Požeška gora fine tuffs to lapilli tuff (samples ŠKR-13, ŠKR-12A and ŠKR-12) were crushed and wet-sieved to obtain material for geochemical analysis.

\section{Electron microprobe}

A JEOL JXA 8200 wavelength-dispersive electron microprobe (EMP) at GEOMAR, Kiel was used for spot analyses of major elements in glasses. EMP analyses were conducted at $15 \mathrm{kV}$ accelerating voltage with a beam current of $6 \mathrm{nA}$, following the procedures and settings of Kutterolf et al. (2011) for felsic glass. The counting time for the signal was $20 \mathrm{~s}$ and $10 \mathrm{~s}$ for the background for major elements, $30 \mathrm{~s}$ and $15 \mathrm{~s}$ for minor elements. The beam was defocused to $5 \mu \mathrm{m}$ to minimize analytical Na loss. For each sample, we made at least 15 individual glass analyses summing up to 221 measured glass shards in total. International natural and synthetic glass standards were used for calibration. Glass analysis of repetitive measurements experienced standard deviations of $<1 \%$ for the major elements $\left(\mathrm{SiO}_{2}, \mathrm{Al}_{2} \mathrm{O}_{3}\right.$, and $<10 \%$ for minor elements $\left(\mathrm{FeO}_{\mathrm{t}}, \mathrm{MgO}, \mathrm{CaO}, \mathrm{K}_{2} \mathrm{O}\right.$, $\mathrm{Na}_{2} \mathrm{O}$, and $\mathrm{TiO}_{2}$ ) regarding glass analysis. Deviations are only $>20 \%$ for $\mathrm{MnO}_{2}$ and $\mathrm{P}_{2} \mathrm{O}_{5}$. Tables of glass compositions and standard measurements can be found in Supplementary Data Table 1.

\section{LA-ICP-MS}

Trace element concentrations of 22 glass shards were determined by laser ablation inductively coupled plasma - mass spectrometry (LA-ICP-MS) at the Institute of Earth Science at the Academia Sinica in Taipei (Taiwan) in 2019. A Photon Machines Analyte G2 laser ablation system using a $193 \mathrm{~nm}$ ArF Excimer laser was set to a spot size of $35 \mu \mathrm{m}$ using $5-6 \mathrm{~J} / \mathrm{cm}^{2}$ energy density at $5 \mathrm{~Hz}$ repetition rate and coupled to a Quadrupole Agilent $7500 \mathrm{cs}$ mass spectrometer. International standard glass (BCR-2g) were measured between sample measurements to monitor accuracy and correct for matrix effects and signal drift in the ICPMS as well as for differences in the ablation efficiency between the sample and the reference material (Günther et al. 1999). Concentrations of NIST reference material SRM 612 were used for external calibration. Silica and calcium concentrations, measured by EMP, were also used as internal standards to calibrate the trace element analyses. For detailed measurement conditions, see Stoppa et al. (2018) and Schindlbeck et al. (2018).

The limit of detection (LOD) for most trace elements is generally not greater than $100 \mathrm{ppb}$. For REEs, the LOD is 


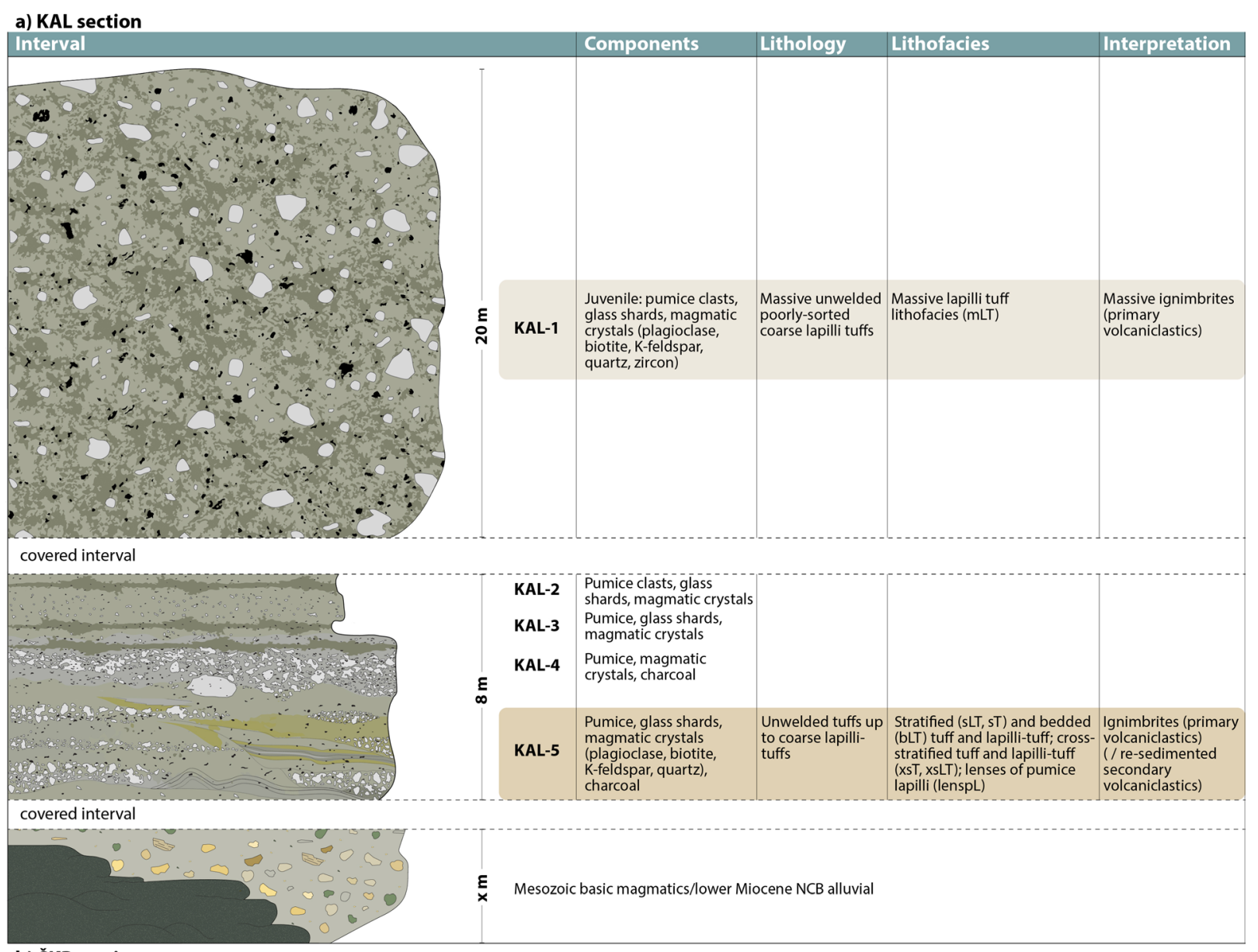

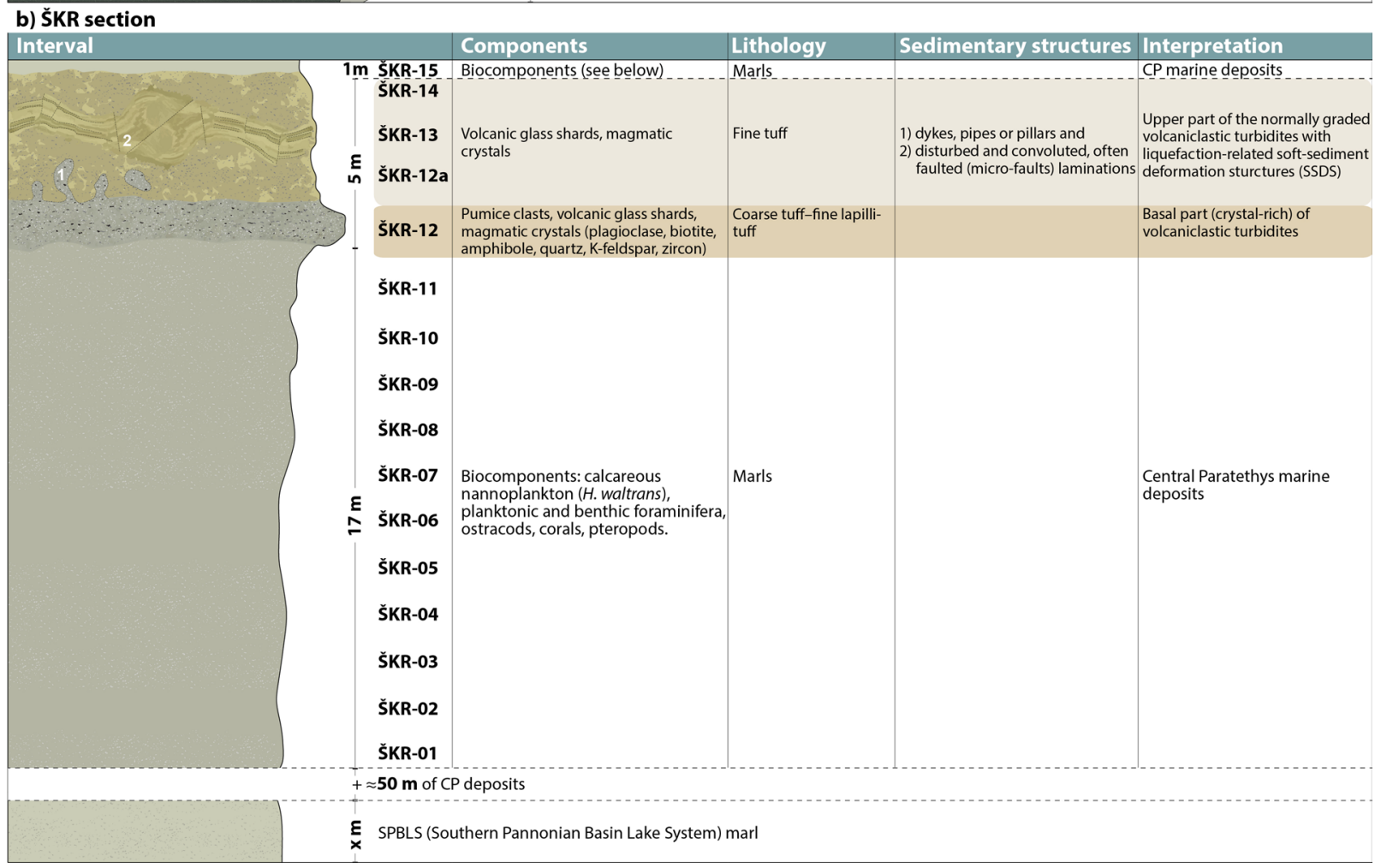


4 Fig. 3 Vertical sections (geological columns) of the KAL (a) and ŠKR (b) sections with summary description and interpretation of lithological members. Lithofacies nomenclature in a adopted from Branney and Kokelaar (2002)

generally around $10 \mathrm{ppb}$. The analytical precision was generally better than $10 \%$ for most trace elements. Trace element compositions including standards and errors are given in Supplementary Data Table 1.

\section{High-precision geochronology}

The premier high-precision geochronometers of the EARTHTIME initiative (Schmitz 2012; Schmitz and Kuiper 2013; Vervoort 2018), forming the framework upon which the relative biochronology and magnetochronology of the Phanerozoic time scale are hung (Gradstein et al. 2012; Schmitz 2018), are:

(1) ${ }^{40} \mathrm{Ar} /{ }^{39} \mathrm{Ar}$ radiometric dating primarily of sanidine feldspar (Kuiper et al. 2008; Rivera et al. 2013; Andersen et al. 2017; Reiners et al. 2018), and

(2) CA-ID-TIMS (chemical abrasion, isotope dilution, thermal ionization mass spectrometry) U-Pb geochronology of zircon (regarded as a "gold standard" of geochronology; Schaltegger et al. 2015; Sahy et al. 2017; Reiners et al. 2018; Wotzlaw et al. 2018).

Different mineral-isotope chronometers may be dating different events or processes; therefore, contributing (amongst other parameters) to the systematic offset between sanidine ${ }^{40} \mathrm{Ar} /{ }^{39} \mathrm{Ar}$ (dating eruption) and zircon $\mathrm{U}-\mathrm{Pb}$ (often recording protracted magmatic evolution) ages (e.g., Rivera et al. 2013; Schmitz and Kuiper 2013; Reiners et al. 2018). However, combining CA-ID-TIMS U-Pb dates of youngest population of zircons with ${ }^{40} \mathrm{Ar} /{ }^{39} \mathrm{Ar}$ ages of sanidine feldspars (using different isotope geochronometers with the goal of obtaining concordant ages between the two systems) represents the most precise and accurate approach to determine the ages of Mts. Kalnik and Požeška gora primary volcaniclastic rocks (KAL-1 and ŠKR-12 intervals, respectively).

\section{Ar/Ar geochronology}

Two volcaniclastic horizons, namely KAL-1 and ŠKR-12, were sampled in the field. Minerals from these layers were separated using standard mineral separation procedures. After crushing and washing, heavy liquid mineral separation with densities of 2.54 and $2.59 \mathrm{~g} / \mathrm{cm}^{3}$ was performed to obtain the sanidine phenocrysts from the samples. Biotite was also separated from both samples. Mineral fractions were further purified by handpicking under an optical microscope. Different grain size factions $(90-180 \mu \mathrm{m}$, 180-250 $\mu \mathrm{m}$ for ŠKR sanidine; $250-500 \mu \mathrm{m}$ for ŠKR biotite; $250-400 \mu \mathrm{m}$ and $400-500 \mu \mathrm{m}$ for KAL sanidine and
250-500 $\mu \mathrm{m}$ for KAL biotite) were packed in a $6 \mathrm{~mm}$ ID AI packages. They were loaded together with Fish Canyon Tuff sanidine (FCs) standards in $25 \mathrm{~mm}$ ID Al cups. Samples and standards were irradiated at the Oregon State University TRIGA reactor in the cadmium shielded CLOCIT facility for $12.6 \mathrm{~h}$ (irradiation code VU117; equivalent to $7 \mathrm{~h}$ of CLICIT position). After irradiation samples and standards were unpacked and loaded in a 185 hole $\mathrm{Cu}$ tray and baked overnight at $250{ }^{\circ} \mathrm{C}$ under vacuum. This tray is then placed in a doubly pumped the vacuum chamber with $\mathrm{Zn}-\mathrm{Se}$ window and baked overnight at $120^{\circ} \mathrm{C}$ under high vacuum. This chamber is connected to a ThermoFisher NGPrep gas purification line equipped with a hot GP50, a cold finger (Lauda at $-70{ }^{\circ} \mathrm{C}$ ) and a hot $\mathrm{St} 707$ getter.

Samples and standards were measured in two different trays (19T13; 19T14). In the first tray, we exposed the feldspar and biotite phenocrysts to a diffuse laser beam under UHV conditions to drive off surficial gasses. The released gas during this pre-heating steps was not measured, but based on previous tests should not contain $>1 \%$ of the ${ }^{39} \mathrm{Ar}_{\mathrm{K}}$ released. Samples in the second tray were not pre-heated. Samples and standards are fused using a $25 \mathrm{~W}$ Synrad $\mathrm{CO}_{2}$ laser. Released gas was analyzed on an ARGUS $\mathrm{VI}^{+}$noble gas mass spectrometer at Vrije Universiteit Amsterdam, The Netherlands. This is a high sensitivity, relatively low-resolution multi-collector noble gas mass spectrometer with an internal volume of $710 \mathrm{ml}$. The resolution of the system is $\sim 200$ and, therefore, does not resolve hydrocarbon or chlorine interferences. The mass spectrometer is equipped with four Faraday cups at the H2, H1, AX, and L1 positions and two compact discrete dynodes (CDDs) at positions L2 and L3. The system is equipped with a $10^{12} \Omega$ amplifier on $\mathrm{H} 2$ and $10^{13} \Omega$ amplifiers on H1, AX and L1 cups. Samples were run on H1-L3 collectors. Similar to Phillips and Matchan (2013) we did not apply bias corrections, but analyzed samples and standards in the same tray (and thus at more or less the same time) alternating with air pipettes with intensities in the same range as the samples and standards. Line blanks were measured every 2-3 unknowns and were subtracted from succeeding sample data.

Data reduction is done in ArArCalc (Koppers 2002). Ages are calculated with Min et al. (2000) decay constants and 28.201 Ma for FCs (Kuiper et al. 2008). The atmospheric ${ }^{40} \mathrm{Ar} /{ }^{36} \mathrm{Ar}$ air value of 298.56 is used (Lee et al. 2006). The correction factors for neutron interference reactions are $(2.64 \pm 0.02) \times 10^{-4}$ for $\left({ }^{36} \mathrm{Ar} /{ }^{37} \mathrm{Ar}\right)_{\mathrm{Ca}}$, $(6.73 \pm 0.04) \times 10^{-4}$ for $\left({ }^{39} \mathrm{Ar} /{ }^{37} \mathrm{Ar}\right)_{\mathrm{Ca}},(1.21 \pm 0.003) \times 10^{-2}$ for $\left({ }^{38} \mathrm{Ar} /{ }^{39} \mathrm{Ar}\right)_{\mathrm{K}}$ and $(8.6 \pm 0.7) \times 10^{-4}$ for $\left({ }^{40} \mathrm{Ar} /{ }^{39} \mathrm{Ar}\right)_{\mathrm{K}}$. All errors are quoted at the $1 \sigma$ level. All relevant analytical data for age calculations can be found in the Supplementary Data Table 2. 


\section{CA-ID-TIMS U-Pb zircon geochronology}

KAL-1 and ŠKR-12 samples were crushed in a tungsten mill and sieved to less than $250 \mu \mathrm{m}$, and then concentrated to heavy minerals using the Wilfley table method (Söderlund and Johansson 2002) and heavy liquids. Following separation, zircons were picked under a binocular microscope. Once zircon grains had been extracted from the samples, they were annealed in a muffle furnace at $900{ }^{\circ} \mathrm{C}$ for $48 \mathrm{~h}$ (Mundil et al. 2004). The annealed grains were then subjected to chemical abrasion at $210^{\circ} \mathrm{C}$ for $12 \mathrm{~h}$ in concentrated HF in $3 \mathrm{ml}$ Savillex beakers placed in a Parr digestion vessel (Mattinson 2005; Widmann et al. 2019). The grain fragments remaining after chemical abrasion were then leached on a hotplate at $80{ }^{\circ} \mathrm{C}$ in $6 \mathrm{~N}$ $\mathrm{HCL}$ overnight, followed by further cleaning through four rounds of $7 \mathrm{~N} \mathrm{HNO}_{3}$ in combination with ultrasonication. Individual cleaned zircon crystals were then loaded into individual $200 \mu$ l Savillex microcapsules, spiked with the EARTHTIME ${ }^{202} \mathrm{~Pb}+{ }^{205} \mathrm{~Pb}+{ }^{233} \mathrm{U}+{ }^{235} \mathrm{U}$ tracer solution (calibration version 3; Condon et al. 2015; McLean et al. 2015) and dissolved with about $70 \mu \mathrm{lF}$ and trace $\mathrm{HNO}_{3}$ in a Parr digestion vessel at $210{ }^{\circ} \mathrm{C}$ for $48 \mathrm{~h}$. Following dissolution, the samples were dried down and converted to a chloride by placing them back in the oven overnight in $6 \mathrm{~N} \mathrm{HCl}$. The samples were then dried down again and re-dissolved in $3 \mathrm{~N} \mathrm{HCl}$, and purified to $\mathrm{U}$ and $\mathrm{Pb}$ through anion exchange column chromatography (Krogh 1973). Once purified, the $\mathrm{U}$ and $\mathrm{Pb}$ fractions were combined in cleaned $7 \mathrm{ml}$ Savillex beakers and dried down with trace $\mathrm{H}_{3} \mathrm{PO}_{4}$, prior to loading on outgassed zone-refined $\mathrm{Re}$ ribbon filaments with a $\mathrm{Si}$-gel emitter. $\mathrm{U}$ and $\mathrm{Pb}$ isotope analyses were completed on an Isotopx Phoenix TIMS machine at the University of Geneva. Lead measurements were made in dynamic mode using a Daly photomultiplier, and $\mathrm{U}$ was measured as an oxide in static mode using Faraday cups coupled to $10^{12} \Omega$ resistors. The ${ }^{18} \mathrm{O} /{ }^{16} \mathrm{O}$ oxygen isotope ratio in uranium oxide was assumed to be 0.00205 based on previous measurements of the U500 standard. Mass fractionation of $\mathrm{Pb}$ and $\mathrm{U}$ was corrected using a ${ }^{202} \mathrm{~Pb} /{ }^{205} \mathrm{~Pb}$ ratio of 0.99506 and a ${ }^{238} \mathrm{U} /{ }^{235} \mathrm{U}$ ratio of $137.818 \pm 0.045(2 \sigma)$ (Hiess et al. 2012). All common $\mathrm{Pb}$ was considered laboratory blank and was corrected using the long-term isotopic composition of the Pb blank at the University of Geneva. All data were processed with the Tripoli and Redux U-Pb software packages (Bowring et al. 2011; McLean et al. 2011). All ages were corrected for initial ${ }^{230} \mathrm{Th}$ disequilibrium in the melt using a U/Th ratio of the magma of 3.5. All relevant analytical data for age calculations can be found in the Supplementary Data Table 3.

\section{Results and interpretations}

\section{Stratigraphy and geochemistry of Mt. Kalnik volcaniclastic rocks}

The KAL section, located in the eastern part of Mt. Kalnik (Fig. 2a), is $28 \mathrm{~m}$ thick and is divided into the lower 8-m-thick stratified volcaniclastic rocks (KAL 5-2 horizons) and the upper 20-m-thick massive volcaniclastic deposits (KAL-1 horizon) (Fig. 3a). The contact between the two units is not exposed. The contacts with the underlying and overlying rocks are not exposed in the investigated area. After detailed field investigation of the whole section, samples from intervals KAL- 1 and KAL-5 were subjected to further volcanological, sedimentological, petrographic, and geochemical investigation. High-precision geochronology was only conducted on sample KAL-1.

\section{Stratified volcaniclastic rocks}

The lower KAL volcaniclastic rocks are predominantly composed of pumices (subangular to rounded clasts up to max. $10 \mathrm{~cm}$ in diameter) and volcanic glass shards, and contain also magmatic/eruption crystals (zoned plagioclase, quartz, biotite, K-feldspar sanidine). Assuming these components are juvenile, the lower KAL volcaniclastic rocks can be classified as unwelded tuffs up to coarse lapilli tuffs (Fig. 4a-d), representing primary volcaniclastic-pyroclastic deposits (sensu White and Houghton 2006). Lithic components (volcanics) were present, but only occur sporadically. Structures related to erosion (Fig. 4c), as well as soft sediment deformation structures (SSDS; e.g., the recorded load casts with flames), were also observed. No elutriation pipes are present. Tuffs and lapilli tuffs, particularly in the first $5 \mathrm{~m}$ of the section (sample KAL-5, which also contains abundant charcoal fragments), are stratified, bedded and cross-bedded, with common occurrence of lenses of pumice lapilli (Figs. 3a, 4a-d). Glass compositions from KAL-5A and 5B are rhyolitic (Fig. 5), with 77.38-77.52 wt\% $\mathrm{SiO}_{2}$ (averages per sample) and total alkalis content of 7.48-7.63 wt\% (Supplementary Data Table 1). Most glass shards appear fresh and yield analytical totals typically better that $93 \mathrm{wt} \%$.

The juvenile components of the lower KAL volcaniclastic rocks may be primary (derived directly from erupting magma) or syn-eruptively recycled (sensu White and Houghton 2006). In this case, the lower KAL volcaniclastic rocks (e.g., sample KAL-5) may correspond to non-genetic lithofacies types sensu Branney and Kokelaar (2002), such as stratified (sLT, sT), bedded (bLT) (as well as diffused varieties), and cross-stratified (xsT, xsLT) 


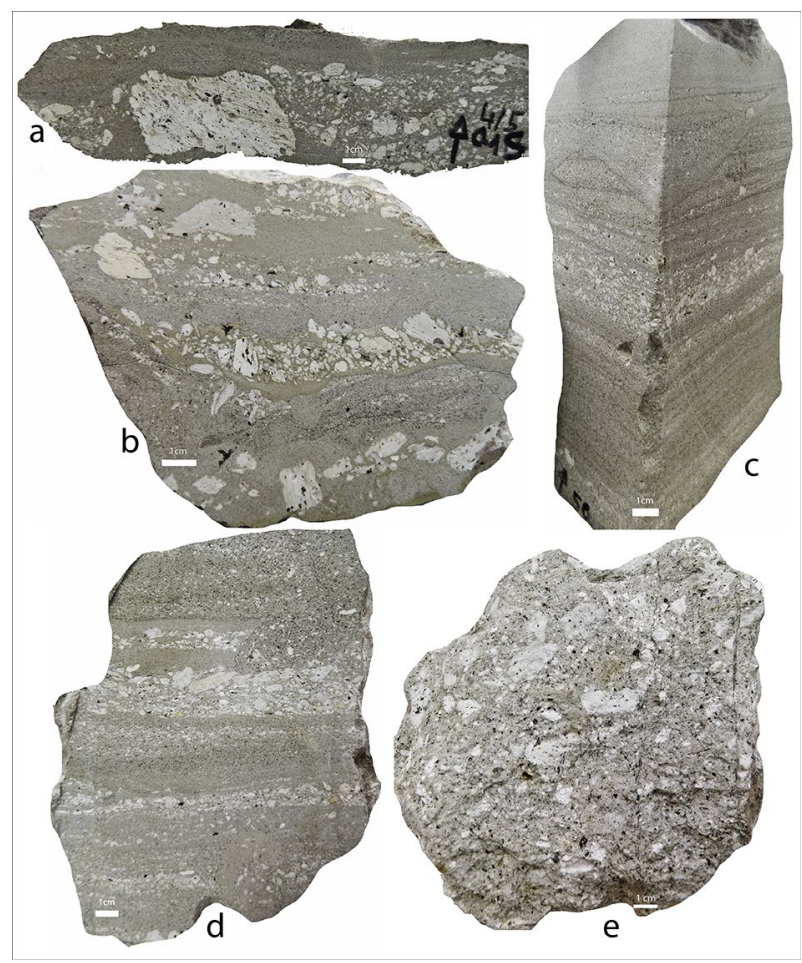

Fig. 4 The volcanological and sedimentological characteristics of the lower (KAL-5; a-d) and upper (KAL-1; e) KAL section volcaniclastic rocks. a-d Unwelded tuffs up to coarse lapilli tuffs (containing charcoal fragments) composed of subangular to rounded pumice clasts, volcanic glass shards and magmatic crystals, arranged in stratified and bedded lithofacies, as well as lenses of pumice lapilli. Probable erosion channel can be observed in c. Although probably deposited from pyroclastic density currents as ignimbrites, KAL-5 volcaniclastic rocks may also represent re-sedimented material. e Unwelded poorly sorted coarse lapilli tuffs (massive ignimbrites) comprising various proportions of subangular to rounded pumice lapilli clasts supported in a matrix of vitric ash and crystal fragments

tuffs and lapilli tuffs, as well as lenses of pumice lapilli (lenspL). According to Branney and Kokelaar (2002), such pyroclastic rocks are classified as ignimbrites deposited from pyroclastic density currents (PDCs) (e.g., Brown and Branney 2004; Hildreth and Firestein 2012; Brown and Andrews 2015). The presence of charcoal, as well as the observed erosion-related and SSD structures, also speaks in favor for the interpretation of lower KAL volcaniclastic rocks as deposited from PDCs (e.g., Branney and Kokelaar 2002; Hudspith et al. 2010; Douillet et al. 2015). However, epiclastic processes (e.g., volcanic glass reworked from previous volcaniclastic deposits) may have also contributed to lower KAL volcaniclastic rocks, and, therefore, the observed sedimentary structures (e.g., in alluvial/fluvial environments; Bull and Cas 2000; Kataoka et al. 2009; van Loon 2009). While stratified, bedded and cross-stratified lithofacies, such as the lower KAL volcaniclastic rocks, represent typical PDC lithofacies types, distinction between deposits related to primary PDCs and those resulting from re-sedimentation of primary volcaniclastics are not often unequivocal, especially at the constrained outcrop scale. While major elemental composition of single glass shards within KAL-5A and 5B completely overlap, their trace elemental compositions (KAL-5B) show conspicuous scatter (Figs. 5, 6, 7, 8; Supplementary Data Table 1). Compositional heterogeneity of volcanic glass shards recorded in a certain volcaniclastic deposit may be caused by different processes, such as postdepositional mixing (reworking) of shards from different volcaniclastic rocks (Lowe et al. 2017). Shards may also have been derived from a compositionally zoned silicic magma body or from different magma sources (Bachmann and Huber 2016 and references therein; Lowe et al. 2017). That said, mechanisms controlling variations in major and trace elemental geochemistry of magmas (especially the silicic ones) vary (e.g., Lowe et al. 2017). In the case of the lower KAL-stratified volcaniclastic rocks, trace elemental compositional heterogeneity of glass shards may have been caused by epiclastic processes (Schneider et al. 2001; Schindlbeck et al. 2013; Cassidy et al. 2014), as suggested by the lithofacies analysis. However, additional geochemical analysis and other data (mineralogy, isotope and zircon petrochronology) may provide additional constraints on the origin of these volcaniclastic rocks and their genetic relationship with the massive ignimbrites.

\section{Ignimbrites}

The upper 20-m-thick KAL volcaniclastic rocks (sample KAL-1) are represented by massive unwelded poorly sorted coarse lapilli tuffs (primary volcaniclastic rocks-pyroclastic rocks—sensu White and Houghton 2006; Fig. 3a). Massive lapilli tuffs lack any internal stratification and are composed of varying abundances of pumice lapilli (subangular to rounded pumice clasts up to max. $10 \mathrm{~cm}$ in diameter) supported in a matrix of vitric ash and crystal fragments (zoned plagioclase, biotite, K-feldspar sanidine and quartz, as well as accessory zircon) (Figs. 3a, 4e). Lapilli tuffs also lack any grading or clast alignment. As well, no elutriation pipes or SSDSs were observed. Glass compositions from KAL-1 are rhyolitic (Fig. 5), with 77.20-77.46 wt\% $\mathrm{SiO}_{2}$ (averages per sample) and total alkalis content of 7.61-7.86 wt\% (Supplementary Data Table 1). Most glass shards appear fresh and yield analytical totals typically better that $93 \mathrm{wt} \%$.

The upper KAL volcaniclastic rocks correspond to massive lapilli tuff lithofacies (mLT sensu Branney and Kokelaar 2002) that are interpreted as massive ignimbrites (sensu Brown and Andrews 2015) and represent the most common ignimbrite lithofacies type (e.g., Brown and Branney 2004; Hildreth and Firestein 2012). Major and trace elemental compositions of single glass shards 


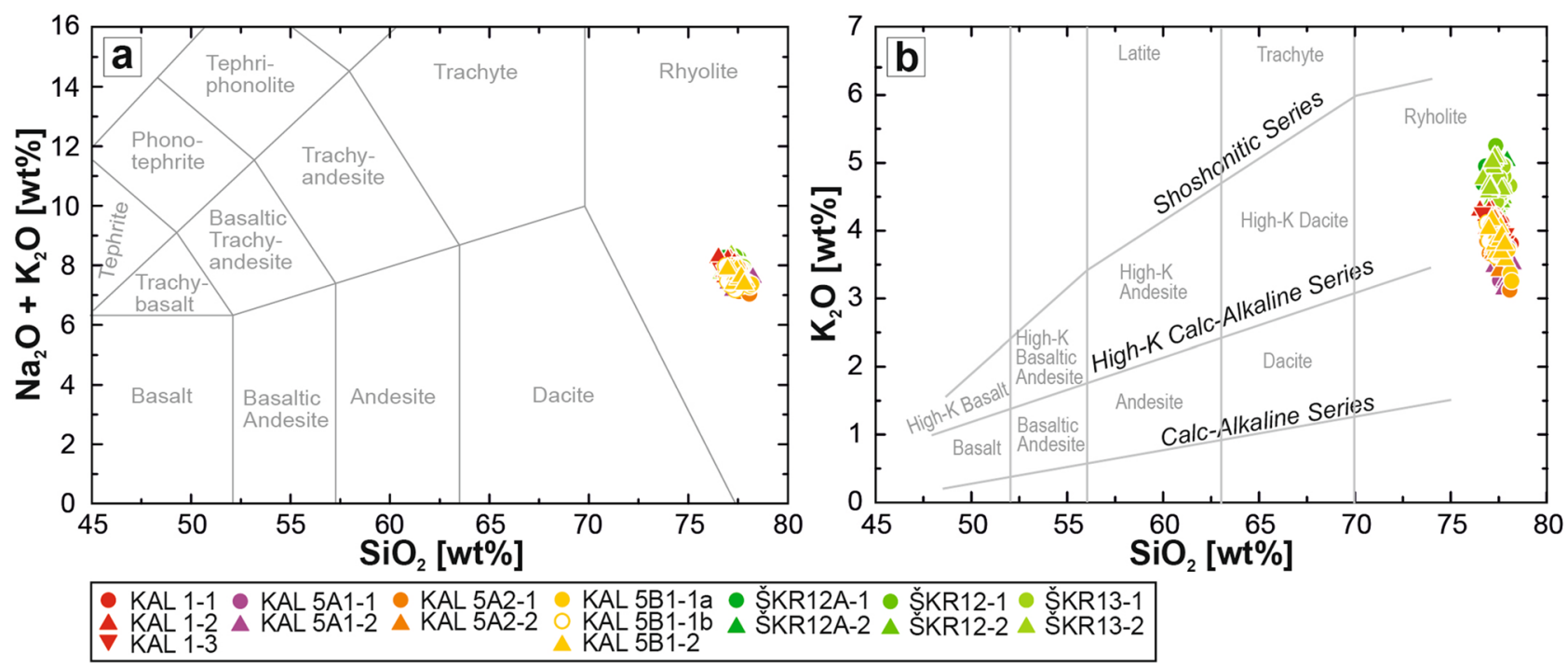

Fig. 5 a Total alkali versus silica plot showing the compositional variability of investigated glasses from Croatian volcaniclastic rocks. b $\mathrm{K}_{2} \mathrm{O}$ vs. $\mathrm{SiO}_{2}$ classification plot for arc rocks after Peccerillo and Tay- lor (1976) with the glass data from the Croatian volcaniclastic rocks. All data are normalized to anhydrous compositions

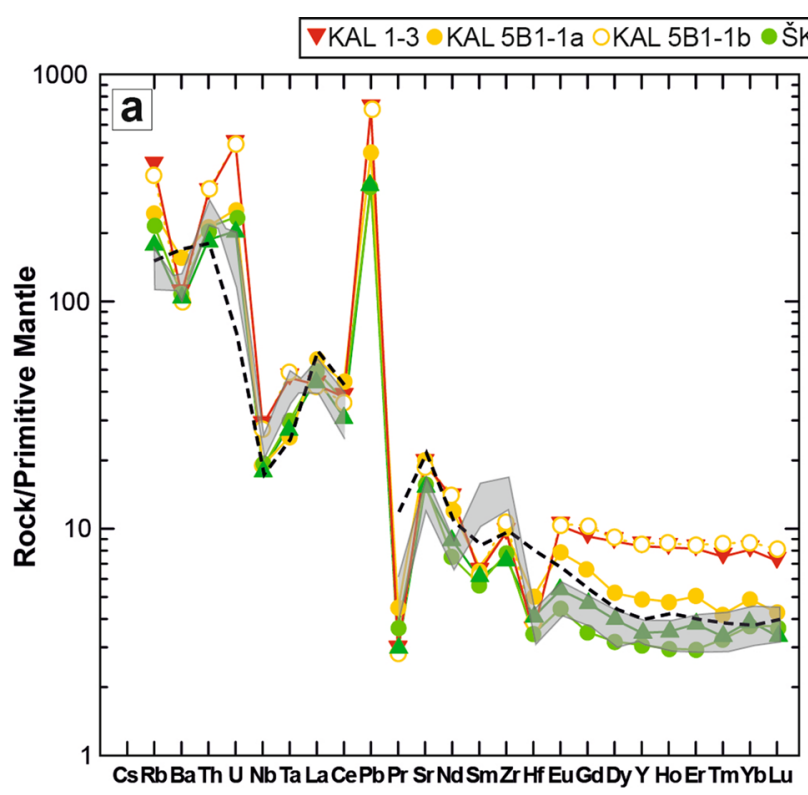

Fig. 6 a Primitive mantle-normalized spider diagram comparing the averaged glass analysis (3-6 individual glass shards) of the felsic Croatian volcaniclastic rocks; normalization after Sun and McDonough (1989). b Chondrite-normalized rare earth element variations of

overlap completely within KAL-1 (Figs. 5, 6, 7, 8; Supplementary Data Table 1). Such homogeneous compositions support our lithofacies-based interpretation that KAL-1 glass components represent juvenile pyroclastic material

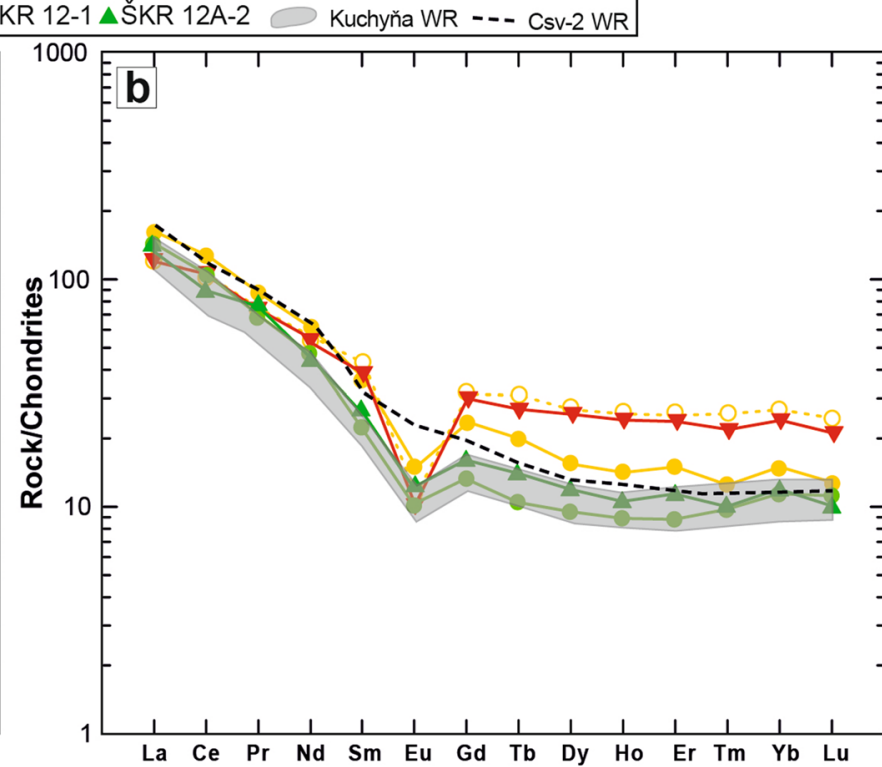

the averaged glass analysis; normalization after McDonough and Sun (1995). Compositions of BVF Csv-2 ignimbrite (Lukács et al. 2018) and Kuchyňa volcaniclastic rocks (Rybar et al. 2019) were also plotted for comparison

from individual eruptive events (Schindlbeck et al. 2013; Kutterolf et al. 2014; see also Cassidy et al. 2014) which produced massive ignimbrites (primary volcaniclastics sensu White and Houghton 2006). 

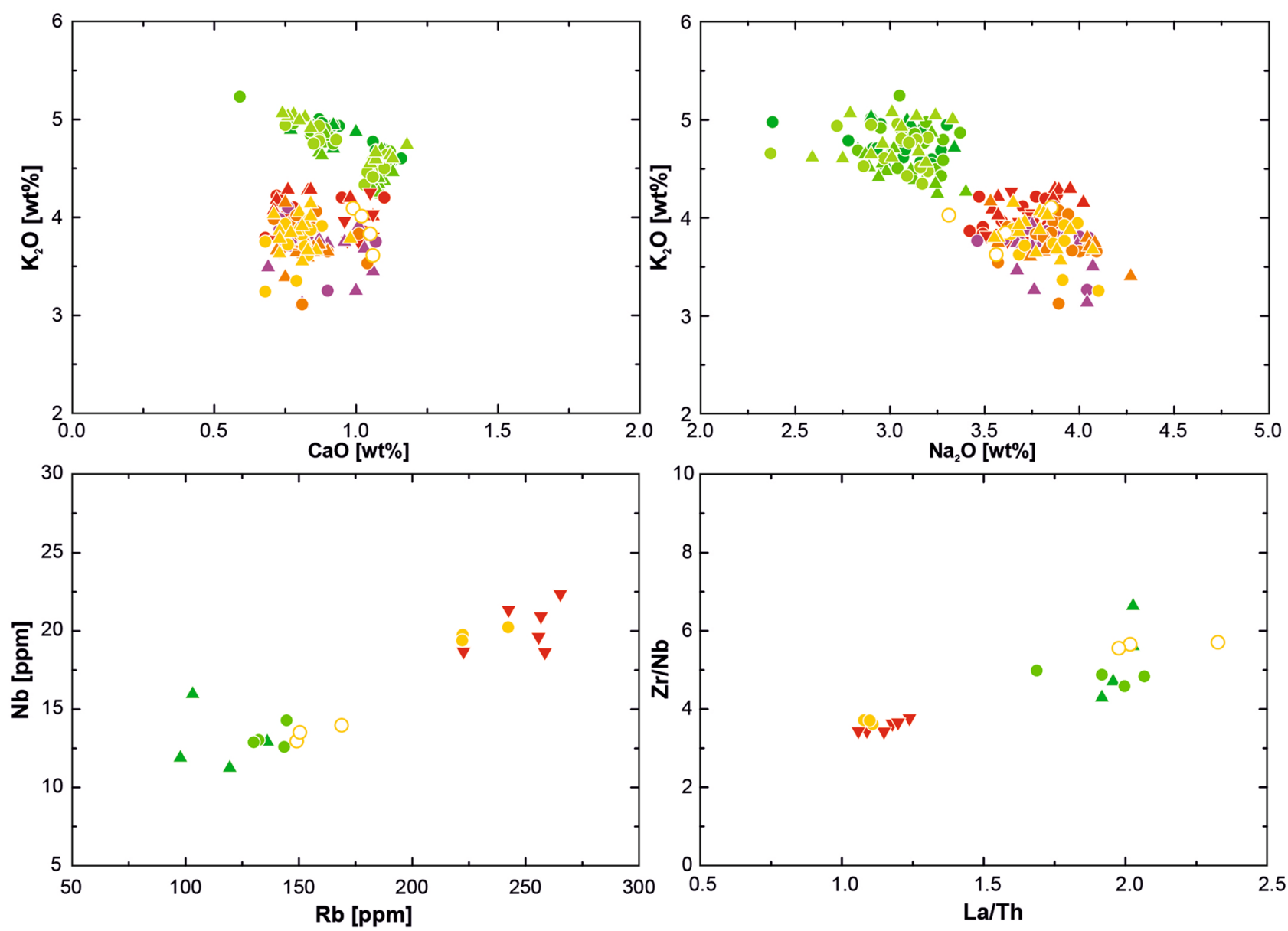

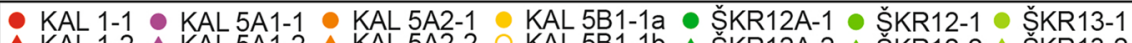

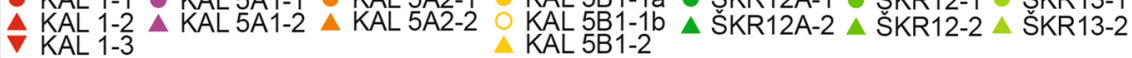

Fig. 7 Major and trace element single glass shard compositions of investigated felsic Croatian volcaniclastic rocks. Besides KAL-5B1, all samples show homogeneous compositions and can be distinguished. All major element data are normalized to anhydrous compositions

\section{Stratigraphy and geochemistry of Mt. Požeška gora volcaniclastic turbidites}

The ŠKR section, located in the central part of Mt. Požeška gora (Fig. 2b), is $23 \mathrm{~m}$ thick and is represented by intercalated volcaniclastic (measuring a total of $5 \mathrm{~m}$ in thickness) and marine sedimentary deposits (Fig. 3b). The volcano-sedimentary complex is underlain by NCB lacustrine deposits (the direct contact is not exposed in the investigated area). After field investigation of the whole-section, volcaniclastic samples from intervals ŠKR-12, 12A and 13 were subjected to further volcanological, sedimentological, petrographic, and geochemical investigation. High-precision geochronology was only conducted on sample ŠKR-12.

The 5-m-thick volcaniclastic deposits of the ŠKR section occur in the uppermost portion of the 23-m-thick profile (Fig. 3b). Their intercalation with marls rich in calcareous nannoplankton and foraminifera, marine ostracods, corals and pteropods (which were found also in the volcaniclastics, together with diatoms), is an indication of their deposition in submarine environments. Volcaniclastics are normally graded, the base of the section is very coarse tuff-fine lapilli tuff (sample ŠKR-12), following the terminology suggested by White and Houghton (2006). It is composed of rounded pumice clasts, volcanic glass shards and crystal fragments (zoned plagioclase, biotite, amphibole, quartz, K-feldspar and accessory zircon) (Fig. 9a). The coarse tuff grades upward into a fine tuff (samples ŠKR-12A, 13, 14; Fig. 9b-f) composed predominantly of volcanic glass shards (and the same mineral phases as ŠKR-12). According to Carey and Schneider (2011; and references therein), several mechanisms may be responsible for the overall flux of volcaniclastics in marine environments: gravitational settling (fallout), sediment gravity flows (including volcaniclastic turbidites, debris flows and submarine pyroclastic flows), as well as reworking of submarine volcaniclastic deposits. 


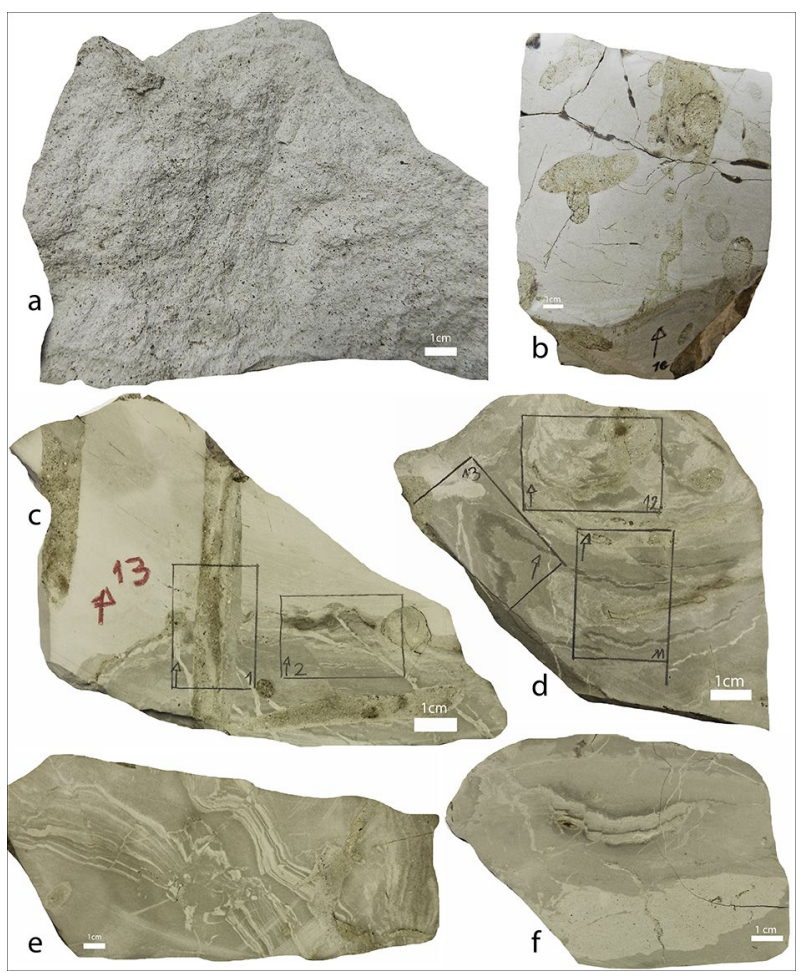

Fig. 8 The volcanological and sedimentological characteristics of the basal crystal-rich (ŠKR-12; a) and the upper part (ŠKR-12A, 13, $14 ; \mathbf{b}-\mathbf{f})$ of normally graded volcaniclastic turbidites of the ŠKR section. a Very coarse tuff-fine lapilli tuff composed of rounded pumice clasts, volcanic glass shards and magmatic crystal fragments. b-f Fine tuff composed predominantly of volcanic glass shards. Soft sediment deformation structures (SSDS) recorded are: a dykes (pipes or pillars) representing coarse tuff-filled irregular structures of various shape and orientation (often vertical), rooted in a basal coarse tuff horizon and cutting through the overlying deformed laminated fine tuff division (b, c), and $\mathbf{b}$ disturbed and convoluted micro-faulted laminations (often floating as fragments within the massive sediment; c-f)
Sharp basal contacts with the underlying sediments, as well as normal grading with a crystal-rich base (both features characterizing ŠKR volcaniclastic rocks) are common both to fallout and sediment gravity flow (turbidites) deposits. Neither bioturbation (often characterizing fallout volcaniclastic rocks) nor rip-up clasts (illustrating the erosive nature of turbidites) were observed in ŠKR volcaniclastic rocks. However, several recorded features may have implications on the origin of ŠKR volcaniclastic rocks, most importantly soft sediment deformation structures (SSDS) observed in the upper finer-grained division of the package, which was likely host to planar laminations. The most pronounced and indicative SSD structures are dykes, pipes or pillars (Lowe 1975; Douillet et al. 2015; Di Capua and Groppelli 2016; no bioturbation trace fossils: e.g., Miller 2006) representing coarse tuff-filled irregular structures of various shape and orientation (often vertical), rooted in a basal coarse tuff horizon and cutting the overlying deformed laminated fine tuff division (Fig. 9b, c). Another indicative SSDS are disturbed and convoluted, often faulted (micro-faults) laminations (Owen et al. 2011), whose lateral continuity cannot be traced (and which can be found as fragments "floating" within the massive sediment) (Fig. 9d-f). Dykes (filled with coarse tuff) in submarine deposited ŠKR volcaniclastic rocks can be regarded as water-escape structures caused by liquefaction and fluidization processes (Lowe 1975; Owen et al. 2011), and fluid-escape structures are commonly present in deposits related to fluidized flows (turbidites; Lowe 1975; Carey and Schneider 2011; Owen et al. 2011; Shanmugam 2017). Disturbed and convoluted (originally planar) laminations are also a common feature of turbidites and could as well be related to liquefaction and fluidization processes.

Based on the above-described characteristics of the ŠKR volcaniclastic rocks, we interpret them as turbidites deposited from sediment gravity flows. Their exact classification as primary (syn-eruptive volcaniclastics with juvenile
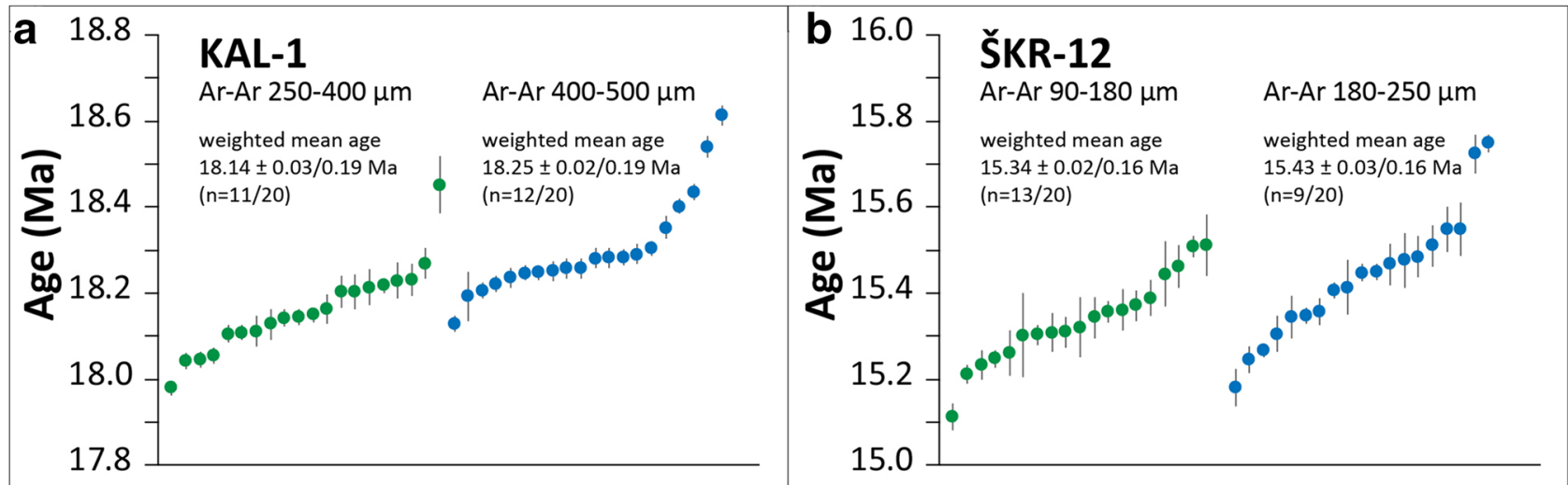

Fig. 9 Age distributions of individual ${ }^{40} \mathrm{Ar} /{ }^{39} \mathrm{Ar}$ age with $1 \sigma$ error. The spread in ${ }^{40} \mathrm{Ar} /{ }^{39} \mathrm{Ar}$ individual ages prevents unambiguous determination of eruption (and therefore sedimentation) age 
components; White and Houghton 2006) or secondary volcaniclastic turbidites (sensu Schneider et al. 2001; Carey and Schneider 2011) may be challenging, since the source material for volcaniclastic turbidity currents can be very variable (e.g., subaerial explosive eruptions producing pyroclastics that are discharged into the sea by pyroclastic flows as well as reworking of unconsolidated volcaniclastic material previously deposited in submarine environments; Schindlbeck et al. 2013) and both types of turbidites may show very similar lithofacies characteristics. Trofimovs et al. (2008) and Di Capua and Groppelli (2016) described subaerially generated PDCs that entered the water and have been disaggregated by the mix between air and water and deposited as syn-volcanic turbidites (Di Capua and Groppelli 2018). In this case, the recorded dykes could also be regarded as gas pipes (e.g., Branney and Kokelaar 2002), with elutriation of fines enhanced by the escape of vaporized water if subaerially generated PDCs were subsequently moved subaqueously. Glass compositions from ŠKR-12 (basal very coarse tuff), as well as ŠKR-12A and ŠKR-13 (upper division fine tuffs), are rhyolitic (Fig. 5), with $77.43 \mathrm{wt} \%$ and 77.14-77.64 wt $\% \mathrm{SiO}_{2}$ (averages per sample), respectively, and have a total alkalis content of 7.59-7.9 wt\% and 7.68-7.88 wt\%, respectively (Supplementary Data Table 1). Most glass shards appear fresh and yield analytical totals better that $93 \mathrm{wt} \%$. Major and trace elemental compositions of single glass shards overlap completely within ŠKR-12 as well as within ŠKR-12A and ŠKR-13 (Figs. 5, 6, 7, 8; Supplementary Data Table 1). In addition, there are only small chemical variations between the glass shards from basal coarse and upper fine tuffs. Such homogeneous compositions support our lithofacies-based interpretation that ŠKR glass components could represent juvenile pyroclastic material of individual eruptive events, and that ŠKR volcaniclastic succession probably represent normally graded primary syn-eruptive volcaniclastic turbidites (Schneider et al. 2001; Carey and Schneider 2011; Schindlbeck et al. 2013; Kutterolf et al. 2014; see also Cassidy et al. 2014).

\section{High-precision geochronology of Mts. Kalnik and Požeška gora volcaniclastics}

\section{Ar/Ar dating results and age interpretation: KAL-1 massive ignimbrites}

We performed ten fusion experiments with one grain/ fusion and ten fusion experiments with 4-5 grains/fusion on 250-400 $\mu \mathrm{m}$ KAL-1 sanidine (VU117-A4). The data scatter from 17.98 to $18.21 \mathrm{Ma}$ with one outlier of 18.45 Ma. Due to the spread in ages (Fig. 10a; Supplementary Table Data 2 ), it is difficult to derive an eruption age accurately. When the highest number of analyses are included with an MSWD smaller than the $t$ test statistic at 95\% confidence level, we

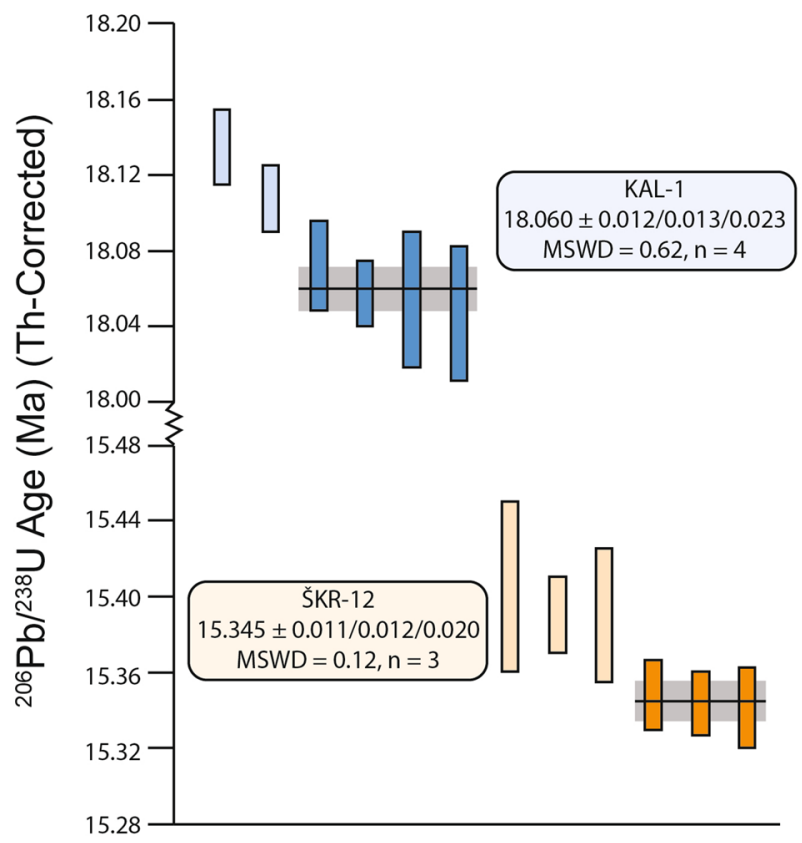

Fig. 10 Weighted mean plot of ${ }^{206} \mathrm{~Pb}-{ }^{238} \mathrm{U}$ zircon ages from volcaniclastic samples of the Miocene North Croatian Basin. The weighted mean ages for each sample are reported as $2 \sigma$ uncertainty given as: internal only/internal with tracer calibration/internal, tracer calibration and with ${ }^{238} \mathrm{U}$ decay constant. Vertical bar heights are the $2 \sigma$ analytical uncertainties for individual analyses as well as the weighted means. Grains not included in these weighted means are shown in lighter colors, see text for discussion

calculate a weighted mean age of $18.14 \pm 0.03 / 0.19 \mathrm{Ma}$ (analytical error/full external $1 \sigma$ error; $n=11 / 20$ ).

20 fusion experiments with 1 grain/fusion were performed on 400-500 $\mu \mathrm{m}$ KAL-1 sanidine (VU117-A5). The data scatter from 18.13 to $18.61 \mathrm{Ma}$. Due to the spread in ages (Fig. 10a; Supplementary Table Data 2), it is difficult to derive an eruption age accurately. When the highest number of analyses are included with an MSWD smaller than the $t$ test statistic at $95 \%$ confidence level, we calculate a weighted mean age of $18.25 \pm 0.02 / 0.19$ Ma (analytical error/full external $1 \sigma$ error; $n=12 / 20$ ).

Ten single biotite grains $(250-500 \mu \mathrm{m})$ of KAL-1 were analyzed (VU117-A6; Supplementary Table Data 2). Their ${ }^{40} \mathrm{Ar} *$ radiogenic range between 7 and $80 \%$ and their ages are spread between 12.3 and $18.5 \mathrm{Ma}$. The radiogenic ${ }^{40} \mathrm{Ar}$ yields suggest presence of alteration and/or ${ }^{40} \mathrm{Ar}$ loss from the biotite and no reliable eruption age was obtained.

\section{$\mathrm{Ar} /$ Ar dating results and age interpretation: ŠKR-12 primary volcaniclastic turbidites}

We performed ten fusion experiments with five grains/fusion and ten fusion experiments with $8-10$ grains/fusion on 90-180 $\mu \mathrm{m}$ ŠKR-12 sanidine (VU117-A1). The data scatter 
from 15.11 to $15.51 \mathrm{Ma}$ with one outlier of 16.48 Ma. Due to the spread in ages (Fig. 10b; Supplementary Table Data 2 ), it is difficult to derive an eruption age accurately. When the highest number of analyses are included with an MSWD smaller than the $t$ test statistic at $95 \%$ confidence level, we calculate a weighted mean age of $15.34 \pm 0.02 / 0.16 \mathrm{Ma}$ (analytical error/full external $1 \sigma$ error; $n=13 / 20$ ).

10 fusion experiments with two grains/fusion and ten fusion experiments with 4-5 grains/fusion were performed on 180-250 $\mu \mathrm{m}$ ŠKR-12 sanidine (VU117-A2). The ages range from 15.18 to $15.75 \mathrm{Ma}$ with one outlier of $17.20 \mathrm{Ma}$. Due to the spread in ages (Fig. 10b; Supplementary Table Data 2), it is difficult to derive an eruption age. When the highest number of analyses are included with an MSWD smaller than the $t$ test statistic at 95\% confidence level, we calculate a weighted mean age of $15.43 \pm 0.03 / 0.16 \mathrm{Ma}$ (analytical error/full external $1 \sigma$ error; $n=9 / 20$ ).

Ten single biotite grains $(250-500 \mu \mathrm{m})$ of ŠKR-12 were analyzed (VU117-A3; Supplementary Table Data 2), but show very low ${ }^{40} \mathrm{Ar} *$ radiogenic yields of $\sim 1 \%$. This suggests alteration and $/ \mathrm{or}^{40} \mathrm{Ar}$ loss from the biotite and no reliable eruption age could be obtained.

\section{$\mathrm{U}-\mathrm{Pb}$ zircon geochronology and age interpretation}

Th-corrected ${ }^{206} \mathrm{~Pb} /{ }^{238} \mathrm{U}$ zircon age determinations are used for all interpretations because this chronometer provides the most precise and accurate values for rocks of this age

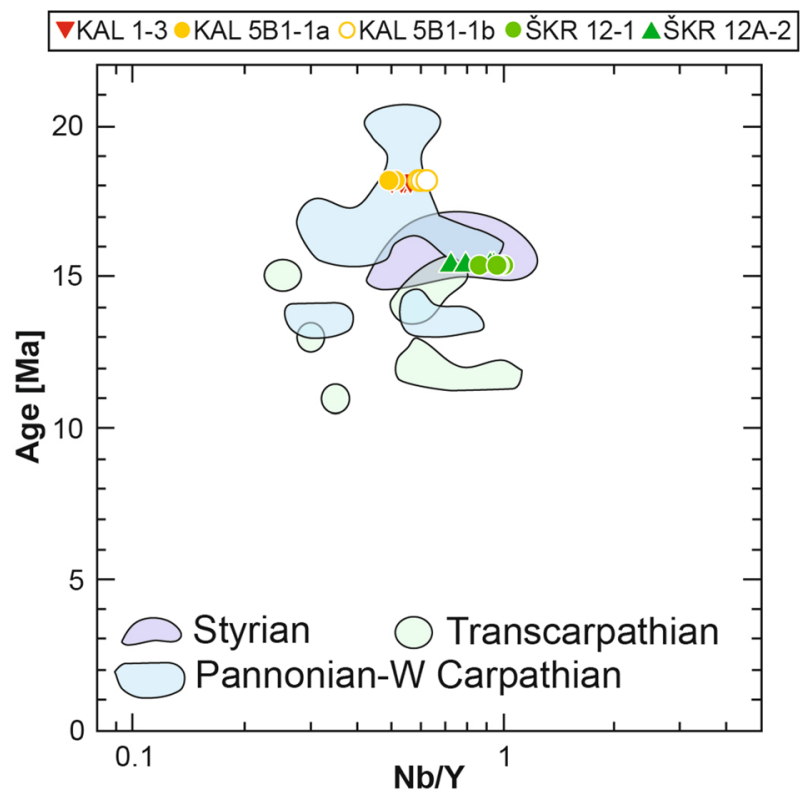

Fig. $11 \mathrm{Nb} / \mathrm{Y}$ vs. age (Ma) diagram after Seghedi and Downes (2011) for the here investigated felsic Croatian volcaniclastic rocks. Provenance fields for felsic volcanics from Western Carpathians and Pannonian, Transcarpathian, and Styrian basins for comparison are from Seghedi and Downes (2011)
(Fig. 11; Supplementary Data Table 3; Supplements 1,2). Individual zircon grains of the KAL-1 coarse lapilli tuff (massive ignimbrite) gave ${ }^{206} \mathrm{~Pb} /{ }^{238} \mathrm{U}$ ages ranging from 18.054 to $18.135 \mathrm{Ma}$, with four grains overlapping within uncertainty at $18.060 \mathrm{Ma}$ (Fig. 11). There was also one normally discordant grain at $23.837 \mathrm{Ma}$. The ŠKR-12 coarse tuff (basal part of the primary volcaniclastic turbidites) yielded an abundance of zircons with minor inclusions. The ${ }^{206} \mathrm{~Pb} /{ }^{238} \mathrm{U}$ zircon ages of the six grains dated in this study range from 15.348 to $15.405 \mathrm{Ma}$, with two populations, one centered around $15.345 \mathrm{Ma}$ and the other at $15.392 \mathrm{Ma}$ (Fig. 11).

Zircon ages from the samples dated in this study have a geochronological range beyond the uncertainty of individual analyses, and, therefore, the full age spectra does not necessarily reflect the age of ignimbrite emplacement and deposition of volcaniclastic rocks. This is a common result among high-precision CA-ID-TIMS zircon geochronology (e.g., Wotzlaw et al. 2013; Samperton et al. 2015; Reiners et al. 2018; Szymanowski et al. 2019), and, therefore, calculating an age for these samples requires further interpretation. There are several common methods to interpret complicated zircon data: (1) antecrysts are common in silicic magma systems, so only the youngest zircon reflects the eruption (e.g., Schaltegger et al. 2009); (2) prolonged magma crystallization is captured by the full zircon spectra, and as a result the full chronologic range represents the solidification of a magma (e.g., von Quadt et al. 2011; Wotzlaw et al. 2013); and (3) samples can contain both antecrystic grains and grains suffering from $\mathrm{Pb}$ loss depending on their composition and geologic history (e.g., Ovtcharova et al. 2015; Gaynor et al. 2019). It is improbable that $\mathrm{Pb}$ loss would uniformly offset the age of zircons grains, and the $12 \mathrm{~h}$ chemical abrasion technique used in this study has been shown to minimize $\mathrm{Pb}$ loss in zircon samples (Widmann et al. 2019). Therefore, we interpret that the youngest population from both samples reflect the age of these samples (e.g., Schaltegger et al. 2015; Sahy et al. 2017; Wotzlaw et al. 2018), with older grains representing antecrystic zircons. The weighted mean and uncertainties associated with this interpretation are $18.060 \pm 0.012 / 0.013 / 0.023 \mathrm{Ma}$ for KAL-1 and 15.345 $\pm 0.011 / 0.012 / 0.020$ Ma for ŠKR-12 ( $2 \sigma$ uncertainty given as: internal only/internal with tracer calibration/internal, tracer calibration and with ${ }^{238} \mathrm{U}$ decay constant) (Fig. 11).

\section{Comparison of $\mathrm{Ar} / \mathrm{Ar}$ and $\mathrm{U}-\mathrm{Pb}$ data}

To compare these data sets, it is necessary to compare the two data sets with the appropriate amount of uncertainty, and, therefore, include internal uncertainty, trace calibration uncertainties, and uncertainties responding to the decay constants of the parental isotopes of interest. Therefore, for 
comparison of the two new geochronology datasets, we report them here using these total uncertainties at the $2 \sigma$ level. For sample KAL-1, the Ar/Ar sanidine measurements yielded ages of $18.14 \pm 0.38 \mathrm{Ma}$ and $18.25 \pm 0.38 \mathrm{Ma}$, which is coeval with the U-Pb zircon age of $18.060 \pm 0.023 \mathrm{Ma}$. For sample ŠKR-12, the Ar/Ar sanidine analyses yielded ages of $15.34 \pm 0.32 \mathrm{Ma}$ and $15.43 \pm 0.32 \mathrm{Ma}$, which is also coeval with the $\mathrm{U}-\mathrm{Pb}$ zircon age of $15.345 \pm 0.020 \mathrm{Ma}$. Therefore, for both samples, the Ar/Ar and U-Pb geochronology are within uncertainty of each other, yielding the same ages. The biotite age spectra are considered irrelevant to these comparisons for either sample, because of the difficulty in determining an Ar diffusion age spectra representative of the eruption history of these rocks.

\section{Discussion}

\section{Mts. Kalnik and Požeška gora silicic volcaniclastics: current status and correlation potential}

Several authors have discussed the geodynamic setting of the $\mathrm{NCB}$, as well as the setting of the HZB volcanics and volcaniclastic sequences and ascribed them to different zones/ segments (Pamić and Balen 2001a; Pécskay et al. 2006; Seghedi and Downes 2011; Mandic et al. 2012; Szakács et al. 2018). Review articles dealing with the overall CPR magmatic and geodynamic evolution, such as Pécskay et al. (2006) and Szakács et al. (2018), considered the genesis of 23-21 Ma calc-alkaline magmatic rocks occurring along the Drava-Sava fault system (south-westernmost edge of the western segment of the intra-Carpathian area) as not unequivocally linked to the CPR system (see also Pamić and Balen 2001a). Seghedi and Downes (2011) settled the 22.8-7.4 Ma calc-alkaline and K-alkalic volcanic rocks present in Sava depression at the southern boundary of CPR. According to the geochronological and geochemical data presented here, we suggest that both KAL and ŠKR volcaniclastic rocks are associated with the CPR magmatic and geodynamic system.

The ages of Mts. Kalnik and Požeška gora felsic massive ignimbrites and volcaniclastic turbidites, derived from integrated high-precision $\mathrm{Ar} / \mathrm{Ar}$ and $\mathrm{U}-\mathrm{Pb}$ geochronology (Figs. 10, 11), fit into the time range of the long-lasting CPR magmatic activity (Fig. 7; Pécskay et al. 2006; Harangi and Lenkey 2007; Seghedi and Downes 2011; Lukács et al. 2018; Szákacs et al. 2018). According to Seghedi and Downes (2011), felsic (silicic sensu Harangi and Lenkey 2007) pyroclastic rocks $\left(>70 \mathrm{wt} \% \mathrm{SiO}_{2}\right.$ ) belonging to the calc-alkaline group were generated during 21-10 Ma (see also Pécskay et al. 2006), and can be found in several CPR basins (e.g., Pannonian and Trascarpathian). According to Lukács et al. (2018), the Early-Middle Miocene was the most intense silicic phase of CPR volcanism (occurring after thermal maturation of the crust that enabled the formation of large upper crustal reservoirs), and was contemporaneous with the major crustal and lithospheric thinning of the Pannonian basin. The initial Early Miocene CPR silicic volcanism was followed by widespread Miocene to Quaternary calc-alkaline andesite-dacite-rhyolite volcanism (Seghedi and Downes 2011; Lukács et al. 2018 and references therein). Tibljaš et al. (2002) and Mandic et al. (2012) correlated the Mt. Kalnik silicic volcaniclastic rocks based on their age and whole-rock geochemical composition with the Upper Oligocene-Lower Miocene (Egerian-Eggenburgian) andesite and dacite lavas and pyroclastic deposits outcropping in north Croatia and belonging to HZB (Pamić et al. 1995; Pamić and Balen 2001a, b). However, while methodological discrepancies (both geochronological and geochemical) do not allow direct comparison, Mt. Kalnik rhyolitic ignimbrites (dated by high-precision geochronology) are younger than the dominantly andesitic volcanics from the HZB (22.8-19.7 Ma based on K-Ar bulk-rock dating; Pamić et al. 1995). According to Mandic et al. (2012) and Pavelić and Kovačić (2018), the Mt. Kalnik volcaniclastic rocks occur intercalated with alluvial sediments representing the base of the NCB continental series, and, therefore, constrain the timing of initial rifting tectonics in the $\mathrm{NCB}$, as the southern portion of the $\mathrm{PB}$. This agrees with previous works indicating that CPR extension-related volcanism started with the eruption of the silicic magmas during the Early Miocene (Pécskay et al. 2006; Seghedi and Downes 2011; Lukács et al. 2018; Szákacs et al. 2018), which matches the geochronology of the Mt. Kalnik rhyolitic ignimbrites (Fig. 7). So far, HZB volcanism was related to the easternmost part of the Periadriatic Fault Zone (PFZ; Rosenberg 2004; see also Handy et al. 2014) and slab breakoff magmatic activity (Pamić and Balen 2001a, b), with Mt. Kalnik volcaniclastic rocks representing the final phase of the andesite-dacite volcanism (Mandic et al. 2012). However, such interpretations are questionable since petrogenesis and geodynamic setting of the Early-Middle Miocene magmatic rocks occurring in the relative vicinity of PFZ is either generally unresolved (Neubauer et al. 2018), or, as is the case of Mt. Pohorje (Slovenia) igneous complex, linked with $\mathrm{CPR}(\mathrm{PB})$ evolution (Fodor et al. 2008, 2020; Poli et al. 2020; see also Schefer et al. 2011; Ji et al. 2019; Kästle et al. 2020).

Not only are the Mts. Kalnik and Požeška gora rhyolitic volcaniclastic rocks contemporaneous with CPR silicic volcanism, they also show general trace elemental geochemistry that can be related to CPR magmatic activity and evolution. High LILE/HFSE ratios, $\mathrm{Pb}$ enrichment, as well as negative $\mathrm{Nb}$, Ta and Ti geochemical signatures, characterizing volcanic glass trace elemental composition of both Mt. Kalnik ignimbrites and Mt. Požeška gora volcaniclastic turbidites, indicates that the magma was derived from an enriched 
Fig. 12 Averaged glass compositions of the investigated felsic Croatian volcaniclastic samples in $\mathrm{Th} / \mathrm{Ta}$ versus $\mathrm{Yb}(\mathbf{a})$ and $\mathrm{Th} /$ $\mathrm{Yb}$ versus $\mathrm{Ta} / \mathrm{Yb}$ (b) geotectonic provenance discrimination plots, modified after Gorton and Schandl (2000)

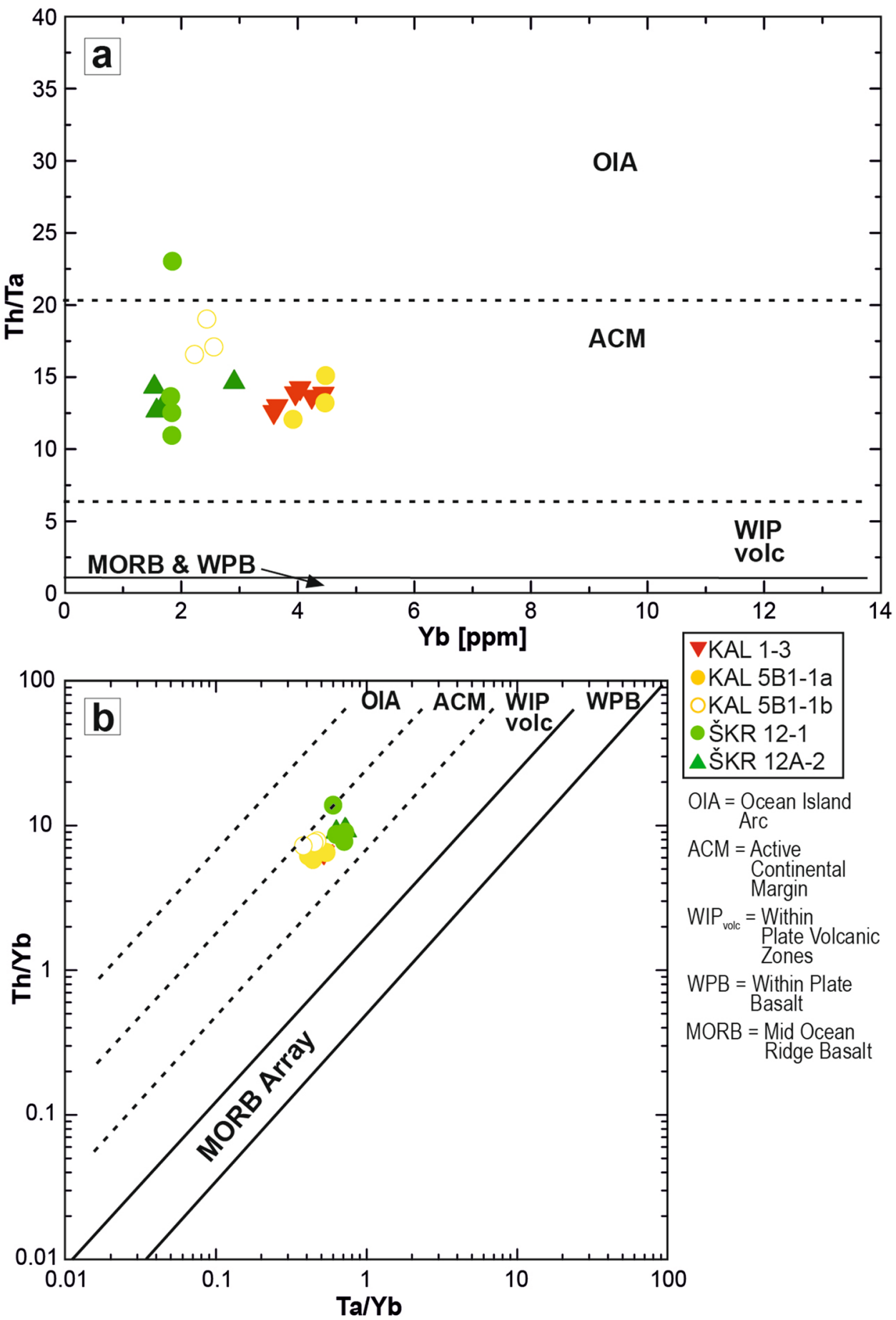

source and has a typical subduction-related geochemical signature (Figs. 7, 8, 12). This geochemical composition has been used to characterize volcanic rocks of the CPR calc-alkaline group, particularly in the western and northern segments, and the current tectonomagmatic model for the generation of these rocks is that they formed in a postcollisional setting (Harangi and Lenkey 2007; Harangi et al. 2007; Seghedi and Downes 2011; Lukács et al. 2018), and were not formed during subduction. Cretaceous-Miocene subduction-related components were preserved in the lithospheric mantle and then subsequently tapped for subsequent magmatism during CPR extension (Seghedi and Downes 2011). Mafic magmas derived from melting of such enriched (metasomatized) lithospheric mantle could have further evolved by crustal assimilation and fractional crystallization to generate silicic magmas (Lukács et al. 2018). The higher $\mathrm{Nb} / \mathrm{Y}$ ratios in the younger ŠKR volcanic glasses, in comparison to older KAL volcanic glasses (Fig. 7) could 
also represent: (A) a lesser proportion of an enriched lithospheric mantle/crustal component than in previous magmatism and/or (B) an increase in an asthenospheric component due to the thinning of the lithosphere driven by continued extension (Seghedi and Downes 2011; Lukács et al. 2018).

Ignimbrite and pyroclastic fall deposits exposed in the Bükkalja Volcanic Field (BVF; AlCaPa Mega-Unit, North Hungary) are the most thoroughly studied silicic volcaniclastic rocks in the CPR area (Lukács et al. 2015, 2018 and references therein), with extensive research into their geochronology, petrogenetic and geodynamic evolution (Fig. 13). Using zircon geochronology (both in situ
LA-ICP-MS as well as CA-ID-TIMS dates), as well as Ar/ Ar sanidine dating, Lukács et al. (2018) concluded that the ignimbrite flare-up volcanism occurred over roughly 4 Myrs (18.2-14.4 Ma). They interpreted that the products of individual large eruption events can be found in different areas across the CPR (both proximal and distal to their presumed volcanic source areas) as well as elsewhere in Europe (North Alpine Foreland Basin and central Italy; Wotzlaw et al. 2014; Rocholl et al. 2018), often as stratigraphically important volcaniclastic marker layers. Concerning NCB, Lukacs et al. (2018) proposed eruptions producing the Harsány $(14.358 \pm 0.015 \mathrm{Ma})$ and the Demjén $(14.880 \pm 0.014 \mathrm{Ma}$;

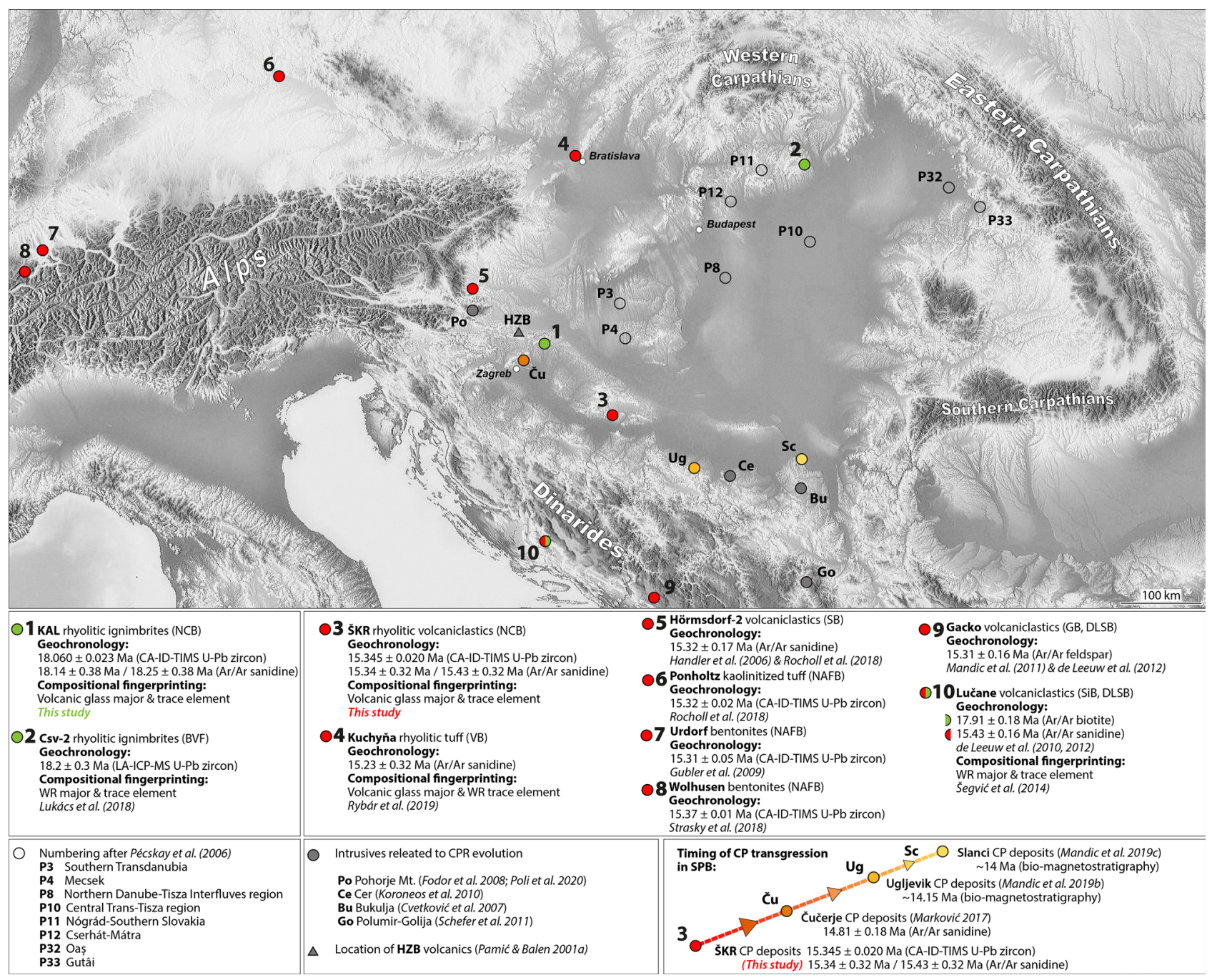

Fig. 13 Occurrences of European volcaniclastic deposits which are age coeval (based on high-precision geochronological data) with KAL ignimbrites (green colored) and SKR volcaniclastic turbidites (colored red). Potential age and compositional volcaniclastic correlatives of KAL and ŠKR volcaniclastic rocks occurring in various Carpathian-Pannonian Region (CPR) areas (marked according to Pécskay et al. 2006 and currently characterized by geochronological and geochemical methodological discrepancy in comparison with
KAL and ŠKR volcaniclastic rocks), as well as locations of intrusives related to CPR geodynamic and magmatic evolution, are also presented. In addition, diachronous timing of initial Central Paratethys (CP) flooding of different parts of the Southern Pannonian Basin (SPB) is indicated. $N C B$ North Croatian Basin, $B V F$ Bükalja Volcanic Field, $S B$ Styrian Basin, $V B$ Vienna Basin, $N A F B$ North Alpine Foreland Basin, $H Z B$ Hrvatsko Zagorje Basin, DLSB Dinaride Lake System Basins, $S i B$ Sinj Basin, $G B$ Gacko Basin 
presumed caldera-forming eruption) BVF ignimbrites as a source for NCB volcaniclastic rocks from Mt. Papuk Nježić locality $(14.40 \pm 0.03 \mathrm{Ma}$ according to Marković 2017) and Mt. Medvednica Čučerje locality $(14.81 \pm 0.08$ Ma according to Marković 2017), respectively, based primarily on geochronological data.

Volcanological, and especially geochronological and geochemical data presented in this paper, can be used for tephrochronological and volcanic provenance reconstructions (e.g., Harangi et al. 2005; Schindlbeck et al. 2016, 2018; Kutterolf et al. 2014, 2018; Lowe et al. 2017; Lukács et al. 2018; Rocholl et al. 2018; Hopkins and Seward 2019). Besides Lukács et al. (2018) and Rocholl et al. (2018) provided the first correlation scheme for volcaniclastic deposits across Europe (including CPR area; overview of Miocene explosive silicic volcanism occurring within and around the Mediterranean area was provided by Lukács et al. 2018). High-precision geochronology is used in this study as a primary constraint for tephrochronological (and volcanic provenance) reconstructions of Mts. Kalnik and Požeška gora volcaniclastic rocks. Geochemical composition of volcaniclastic rocks that have an age coeval with KAL-1 and ŠKR-12 (Fig. 13) should be compared with geochemical composition of Mts. Kalnik and Požeška gora volcaniclastic rocks. However, published major and trace element compositions of individual glass shards from most of the coeval horizons are lacking (see below). In addition, volcanological constraints (e.g., possible travel distances of PDC's from source to depositional area; e.g., Wilson et al. 1995) must also be accounted for when correlating contemporaneous deposits.

Our new CA-ID-TIMS U-Pb zircon data indicate ages (reported using total uncertainties at the $2 \sigma$ level) of $18.060 \pm 0.023 \mathrm{Ma}$ (KAL-1 massive ignimbrites) and $15.345 \pm 0.020 \mathrm{Ma}$ ( ̌́KR-12 primary volcaniclastic turbidites) for volcaniclastic marker beds within the NCB (Fig. 11). The zircon ages are complemented by coeval ${ }^{40} \mathrm{Ar} /{ }^{39} \mathrm{Ar}$ sanidine ages (18.14 $\pm 0.38 \mathrm{Ma}$ and $18.25 \pm 0.38 \mathrm{Ma}$ for KAL-1; $15.34 \pm 0.32 \mathrm{Ma}$ and $15.43 \pm 0.32 \mathrm{Ma}$ for ŠKR-12; $2 \sigma$ level; Fig. 10). Age of the stratigraphically oldest unwelded ignimbrites of the BVF (pumice-bearing lapilli tuff recorded in the Csv-2 borehole), determined by LA-ICP-MS U-Pb zircon dating as 18.2 $\pm 0.3 \mathrm{Ma}$ (Lukács et al. 2018; Fig. 13), is coeval with $\mathrm{U}-\mathrm{Pb}$ and $\mathrm{Ar} / \mathrm{Ar}$ ages of KAL-1 ignimbrites. The ŠKR-12 volcaniclastic turbidites have an age identical to North Alpine Foreland Basin (Upper Freshwater Molasse) volcanic tuffs (Fig. 13), including Swiss Urdorf $(15.31 \pm 0.05 \mathrm{Ma})$ and Wolhusen $(15.37 \pm 0.01 \mathrm{Ma}$; youngest single zircon CA-ID-TIMS U-Pb age) bentonites, as well as southern German Ponholz kaolinitized volcaniclastic rocks $(15.32 \pm 0.02 \mathrm{Ma}$; youngest single zircon CA-IDTIMS U-Pb age) (Gubler 2009; Rocholl et al. 2018; Strasky et al.2018). Due to its ambiguous true age and stratigraphic position, the relationship of Krumbad bentonite (Rocholl et al. 2018) with ŠKR-12 cannot be determined in this study. The 15.32 $\pm 0.17 \mathrm{Ma}$ Ar/Ar biotite age of Hörmsdorf- 2 tuff of the Styrian Basin (Handler et al. 2006; Rocholl et al. 2018; see also Sant et al. 2020) is also coeval with ŠKR12 volcaniclastic rocks (Fig. 13). In addition, Rybár et al. (2019) derived an (eruption) age of $15.23 \pm 0.32 \mathrm{Ma}$ by Ar/ Ar dating sanidines from Kuchyňa tuff of the Vienna Basin (Fig. 13; see also Sant et al. 2020). Both KAL-1 and ŠKR-12 age coeval volcaniclastic deposits are also recorded in Dinaride Lake System Basins (DLSB): $17.91 \pm 0.18 \mathrm{Ma}$ (biotite) and $15.43 \pm 0.16 \mathrm{Ma}$ (sanidine) old tuffs from Sinj Basin (Lučane section), as well as $15.31 \pm 0.16 \mathrm{Ma}$ (feldspar) old tuff from Gacko Basin (de Leeuw et al. 2010, 2012; Mandic et al. 2011). The ŠKR-12 age correlations are currently unknown both from BVF (Lukács et al. 2015, 2018) and published NCB geochronological data (Mandic et al. 2012). Therefore, based on currently available geochronological data, the Mátra-Bükk region can be excluded as a volcanic source for ŠKR-12 volcaniclastic rocks. In addition, it is unlikely for subaerially generated PDCs, representing the probable source for ŠKR syn-eruptive volcaniclastic turbidites, to travel such great distances from the presumed MátraBükk volcanic center.

To make the most reliable and constrained tephrochronological and volcanic provenance reconstructions, major and trace elemental composition of volcanic glasses from agecorrelative volcaniclastics need to be compared (Lowe 2011; Lowe et al. 2017; Hopkins and Seward 2019). Focusing first on the younger unit in this study, ŠKR-12 has several potential correlations with rocks outside of the NCB (Fig. 13). However, the ŠKR-12 correlation and comparison with coeval North Alpine Foreland Basin Urdorf-WolhusenPonholz bentonites and kaolinitized tuff is not easily made, as no volcanic glass was preserved in these rocks (although glass particles preserved in younger volcaniclastic deposits in the southern German part of the Molasse basin revealed exclusively rhyolitic compositions; Rocholl et al. 2018). In addition, no geochemical data exist for Hörmsdorf-2 tuff of the Styrian Basin (Handler et al. 2006). Rybár et al. (2019) presented both whole-rock and volcanic glass geochemical compositions of the Kuchyña tuff of the Vienna basin, which is coeval with ŠKR-12 volcaniclastic rocks. The major element compositions of volcanic glasses of these coeval rhyolitic $\left(\sim 77 \mathrm{wt} \% \mathrm{SiO}_{2}\right)$ volcaniclastic deposits is similar (Supplementary Table Data 1; Rybár et al. 2019). However, to resolve if the ŠKR-12 and Kuchyňa volcaniclastic rocks were derived from the same volcanic source and produced by the same eruption event, additional trace element composition of volcanic glass is required (Harangi et al. 2005; Lowe 2011; Kutterolf et al. 2014; Lowe et al. 2017; Schindlbeck et al. 2018; Hopkins and Seward 2019) as these are not available for the Kuchyña tuff. Instead, comparing the 
whole-rock trace element composition of the Kuchyňa tuff to the ŠKR-12 volcanic glass trace element geochemistry might provide some useful general implications. The composition of both ŠKR-12 volcaniclastic rocks and Kuchyňa tuff show a subduction-related signature (e.g., high LILE/HFSE, Ta-Nb-Ti depletion, Pb enrichment; Fig. 12; Rybár et al. 2019). They also show a similar REE pattern and Eu anomaly $\left(\mathrm{Eu} / \mathrm{Eu}^{*}=0.58\right.$ for $\mathrm{S}^{\mathrm{K} R}-12 ; \mathrm{Eu} / \mathrm{Eu} *=0.59$ for Kuchyňa tuff; Fig. 12; Rybár et al. 2019). Discrimination diagrams point to a certain degree of compositional compatibility between the two volcaniclastic rocks (Fig. 14). In terms of the older marker bed dated in this study, KAL-1 is coeval with BVF Csv-2 (Lukács et al. 2018) rhyolitic ignimbrites. Although both belong to felsic subgroup of CPR calc-alkaline magmatic rocks, more in-depth insight into their genetic relationship is not currently possible, as no volcanic glass major and trace elemental geochemistry is available from the Csv-2 ignimbrites. The same is true for variously altered DLSB volcaniclastic deposits (coeval with both KAL-1 and
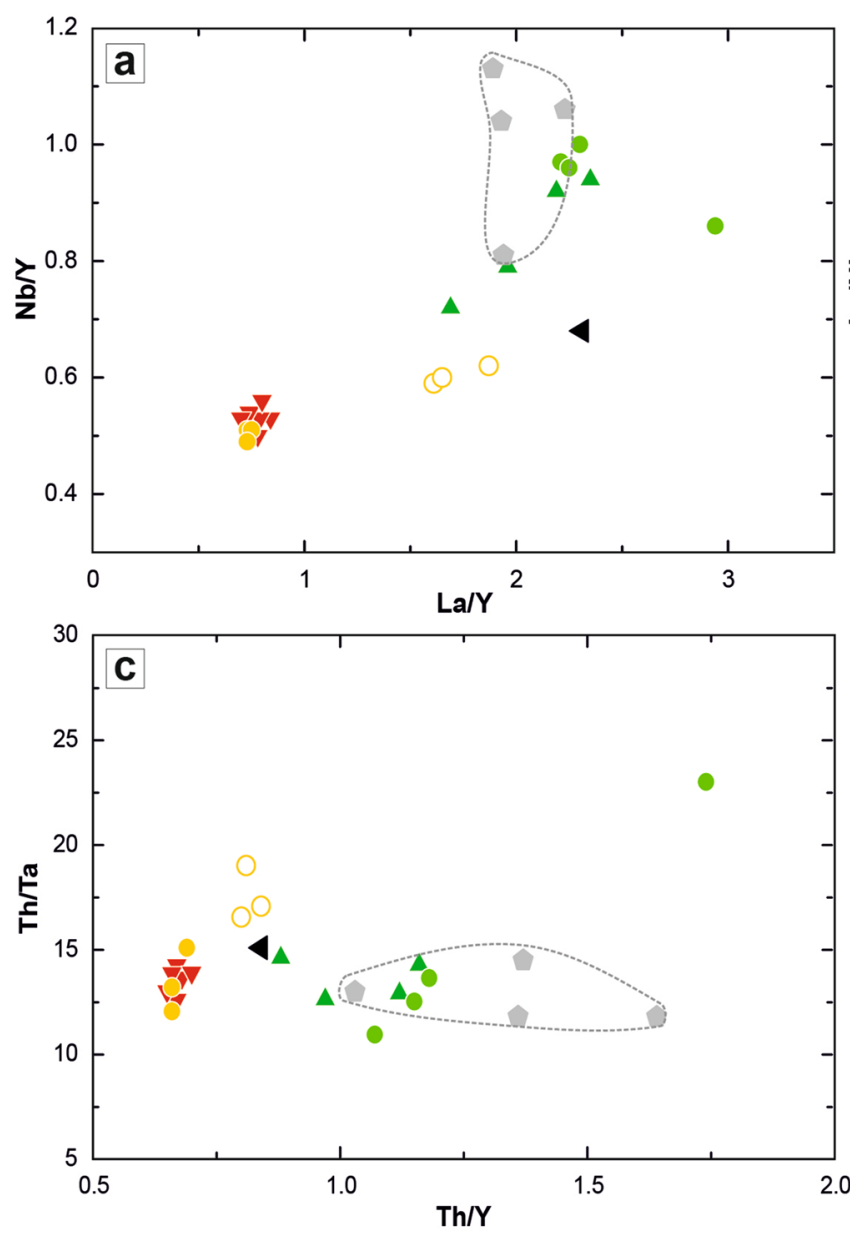

Fig. 14 Discrimination diagrams using different trace element ratios (a Nb/Y vs. La/Y, b La/Nb vs. Th/Nb, c Th/Ta vs. Th/Y) from averaged single glass shard compositions of investigated felsic Croatian volcaniclastic rocks in comparison to trace element whole-rock com-
ŠKR-12 volcaniclastic rocks; de Leeuw et al. 2010, 2012; Mandic et al. 2011; Fig. 13) for which only whole-rock (and bulk volcanic glass) major and trace elemental compositions are available (and were used by Šegvić et al. 2014 for magmatic provenance reconstructions suggesting CPR as a volcanic source area). In conclusion, although the coeval Kuchyňa tuff and Mt. Požeška gora volcaniclastic turbidites, as well as Mt. Kalnik and Csv-2 ignimbrites (Fig. 13), do show some general compositional similarities, methodological discrepancy (outlined in Lowe 2011; Lowe et al. 2017; Hopkins and Seward 2019) prevents making reliable tephrochronological interpretations at this juncture. The current data does suggest that they might have been derived from the same volcanic sources (and potentially produced by the same CPR eruption events). However, to enable most reliable and constrained tephrochronological and volcanic provenance, as well as petrogenetic reconstructions, additional proxies (such as zircon petrochronology; e.g., Szymanowski et al. 2016, 2019; Ellis et al. 2019) are required. Such a multiple
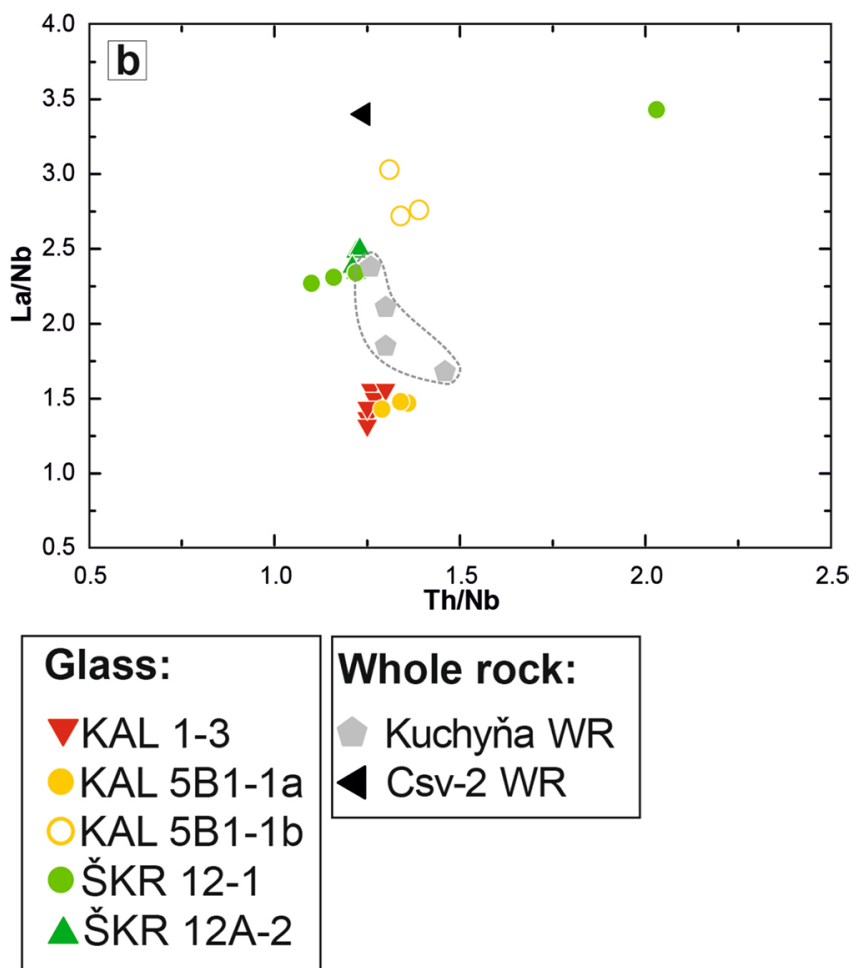

positions of Csv-2 ignimbrite (Lukács et al. 2018) and Kuchyňa tuff (Rybár et al. 2019). Dashed field outline the given compositional variability of the measured Kuchyňa tuff bulk rock samples (Rybár et al. 2019) 
technique approach should be applied on the regional scale (Fig. 13; Pécskay et al. 2006; de Leeuw et al. 2012; Lukács et al. 2018; Rocholl et al. 2018; Szakács et al. 2018) to gain more comprehensive understanding of the CPR geodynamic and magmatic evolution.

\section{Geochronological constraints on the timing of the initial flooding in the NCB with CP implications}

The spatial and temporal evolution of the semi-enclosed Central Paratethys sea during the Early to Middle Miocene, as well as the chronologic framework to disentangle geodynamic and climatic processes affecting depositional environments, is not yet resolved (Hilgen et al. 2012; Sant et al. 2017; Kováč et al. 2018). The CP evolution likely reflects both geodynamically induced changes in basin connectivity (due to development of Alpine-Carpathian-Dinaride orogenic systems), as well as changes in eustatic sea level (Sant et al. 2017, 2019; Kováč et al. 2018; de Leeuw et al. 2018). Although there has been recent progress (e.g., de Leeuw et al. 2018; Sant et al. 2019, 2020), a general lack of high-precision geochronology makes correlation within and between CP basins difficult, as well as making it complicated to correlate these basins to the global time scale (Holcová et al. 2018; Kováč et al. 2018). In addition, Sant et al. (2017) stated the need for using the recently revised Mediterranean Early-Middle Miocene calcareous plankton biochronology in full extent to re-date the Paratethyan successions (due to the connection of the $\mathrm{CP}$ with the Mediterranean through e.g., Trans-Tethyan-Trench Corridor; Holcová et al. 2018; Kováč et al. 2018; Sant et al. 2019). Kováč et al. (2018) also emphasized the importance of taking into account the diachronism of the lithostratigraphy, as well as first appearances of index species.

The initial Miocene CP NCB marine deposits in northern Croatia were first dated as Early Miocene (Karpatian; Pavelić 2001), and were unconformably deposited on different types of basement rocks (pre-Miocene basement as well as Lower-Middle Miocene SPBLS deposits; Ćorić et al. 2009; Brlek et al. 2018; Mandic et al. 2019a). However, according to Ćorić et al. (2009), Mandic et al. (2012, 2019a, b), Marković (2017) and Pavelić and Kovačić (2018 and references therein), initial Miocene marine flooding of the NCB corresponds to the main Badenian (Middle Miocene) transgressive pulse of $\mathrm{CP}$, that is Middle Badenian (NN5 Zone, TB 2.4 after Hohenegger et al. 2014). These recent studies are based on radiometric dating of the volcaniclastic horizons and integrated biostratigraphy, which constrained the age of Lower-Middle Miocene NCB deposits analyzed therein (Mandic et al. 2012; Marković 2017). However, as outlined in Brlek et al. (2018), the precise timing of the initial Early-Middle Miocene flooding of different parts of
NCB is unresolved, primarily because of an insufficient amount of high-precision geochronological data.

The transition from lacustrine to marine deposition, and, therefore, the timing of the initial NCB flooding, was previously interpreted at approximately $15 \mathrm{Ma}$ based on $\mathrm{Ar} / \mathrm{Ar}$ dates and calcareous plankton stratigraphy from volcaniclastic rocks intercalated with both SPBLS and CP deposits present at several NCB localities (Mandic et al. 2012; Marković 2017; Pavelić and Kovačić 2018; Mandic et al. 2019a, b, c; Sant et al. 2019). The same timing of the lacustrine to marine transition was interpreted for Mt. Požeška gora NCB deposits by Mandic et al. (2019a); however, without any isotope geochronology. Our new CA-ID-TIMS U-Pb zircon age of $15.345 \pm 0.020 \mathrm{Ma}$ (Fig. 11) from Mt. Požeška gora (ŠKR section) primary volcaniclastic turbidites intercalated with marine $\mathrm{NCB}$ deposits prove that $\mathrm{CP}$ marine flooding had already occurred in some parts of NCB during the NN4 Zone, contradicting this previous interpretation. This indicates either that the initial transgression may have been diachronous across the NCB (as it is diachronous across the southern margin of Pannonian Basin and across other Central European basins; Mandic et al. 2019a, b, c; Sant et al. 2017, 2019, 2020; Fig. 13), or that different NCB parts could have been initially flooded during different $\mathrm{CP}$ events (Hernitz Kučenjak et al. 2018). On the CP (and whole Paratethys) scale, to enable more reliable reconstructions concerning the timing and mode of the installment of Badenian Sea(s) and onset of flooding(s), such as the widespread "mid-Langhian" one interpreted to occur in most CP regions after 15 Ma (Rybár et al. 2019; Sant et al. 2019, 2020), more high-precision geochronological dates must be derived from individual $\mathrm{CP}$ basins.

\section{Conclusions}

We present the stratigraphy for Mts. Kalnik and Požeška gora volcaniclastic sequences, integrated with high-precision $\mathrm{U}-\mathrm{Pb}$ and $\mathrm{Ar} / \mathrm{Ar}$ geochronological, and volcanic glass geochemistry data, to provide new constraints on their age, magmatic provenance and tephrochronology, as well as on the timing of initial CP flooding of the NCB. This enabled more reliable reconstruction of Miocene syn-rift evolution of the NCB with regional CPR and CP implications.

Mt. Kalnik 20-m-thick pumice-bearing coarse lapilli tuffs (KAL-1 horizon) were deposited from PDCs as massive ignimbrites. Derivation of these rhyolitic (>77 wt\% $\mathrm{SiO}_{2}$ ) ignimbrites from a single eruption event (primary volcaniclastic rocks) was confirmed by homogeneous major and trace elemental composition of juvenile volcanic glass shards. Comparison of KAL-1 high-precision geochronological data (using total uncertainties at the $2 \sigma$ level) indicate that $\mathrm{Ar} / \mathrm{Ar}$ sanidine ages of $18.14 \pm 0.38 \mathrm{Ma}$ and 
$18.25 \pm 0.38 \mathrm{Ma}$ and a CA-ID-TIMS U-Pb zircon age of $18.060 \pm 0.023 \mathrm{Ma}$ are coeval. Major and trace elemental composition of single glass shards from Mt. Požeška gora (ŠKR section) 5-m-thick normally graded volcaniclastic turbidites, characterized by liquefaction-related soft sediment deformation structures (pillars/dykes and disturbed, convoluted and faulted laminations), also overlap completely, rendering these turbidites as primary. High-precision geochronology of the basal interval (ŠKR-12 rhyolitic coarse tuff) of primary volcaniclastic turbidites is also within uncertainty between the two techniques, with a CA-ID-TIMS U-Pb zircon age of $15.345 \pm 0.020 \mathrm{Ma}$ and $\mathrm{Ar} / \mathrm{Ar}$ sanidine ages of $15.34 \pm 0.32 \mathrm{Ma}$ and $15.43 \pm 0.32 \mathrm{Ma}$.

The Mts. Kalnik and Požeška gora rhyolitic ignimbrites and volcaniclastic turbidites, respectively, are coeval with the CPR silicic magmatic activity, which produced widespread felsic calc-alkaline pyroclastic rocks. The Early to Middle Miocene is most intense silicic phase of CPR volcanism, and is generally accepted as being contemporaneous with the major lithospheric thinning of the PB. Geochemical signatures of both the KAL and $\breve{S K R}$ volcaniclastic rocks, as well as of other coeval CPR silicic pyroclastic rocks, can be regarded as subduction-related (e.g., high LILE/HFSE, $\mathrm{Pb}$ enrichment, $\mathrm{Nb}-\mathrm{Ta}-\mathrm{Ti}$ depletion). Such geochemical imprint was previously interpreted to be in direct relation to postcollisional character of CPR volcanism, with subductionrelated components that were preserved in the lithospheric mantle being reactivated during CPR extension.

Based on the high-precision geochronology data, the Mt. Kalnik ignimbrites are coeval with the Csv-2 borehole rhyolitic ignimbrites, from the BVF. The ŠKR-12 volcaniclastic turbidites are coeval in age when compared to the North Alpine Foreland Basin (Switzerland and southern Germany) Urdorf-Wolhusen-Ponholz bentonites and kaolinitized tuffs, as well as with the Styrian Basin Hörmsdorf-2 tuff and the Vienna Basin Kuchyňa tuff. In addition, both Mts. Kalnik and Požeška gora volcaniclastics are coeval with DLSB (Sinj and Gacko Basins) tuffs. This indicates that, based on currently available geochronological data, the presumed Mátra-Bükk area can be excluded as a volcanic source for the NCB ŠKR-12 volcaniclastic rocks. To further resolve if the Mts. Kalnik and Požeška gora and their temporally correlative European volcaniclastic rocks may have been derived from the same volcanic sources and eruption events, major and trace element composition of corresponding volcanic glasses must be compared. However, no data are available from North Alpine Foreland Basin and Styrian basin tuffs. Although the available major element geochemistry of the Kuchyňa rhyolitic tuff is similar as ŠKR-12, analysis of trace elemental composition of volcanic glass of Kuchyña tuff is needed to confirm that the two units share an ancestral volcanic event. Similarly, only whole-rock geochemistry is available from the Csv-2 ignimbrites, which are coeval with KAL-1, as well as from DLSB volcaniclastics. Such methodological discrepancies prevent making reliable tephrochronological and volcanic provenance reconstructions. Instead, to gain a more comprehensive understanding of the CPR geodynamic and magmatic evolution, a multi-proxy approach must be applied on the regional scale.

Our new high-precision geochronology data from the Mts. Požeška gora volcaniclastic rocks, intercalated with NCB marine deposits, provide insight into the timing of the initial Mille Miocene (Badenian) marine flooding (and transition from lacustrine to marine deposition), which is at least $\sim 0.35$ Ma older than generally accepted at the NCB scale (maximally $\sim 15 \mathrm{Ma}$ ). This proves that $\mathrm{CP}$ marine flooding occurred in some parts of NCB during the NN4 Zone, and that the initial transgression might have been diachronous across the NCB, or that different NCB parts could have been initially flooded during different $\mathrm{CP}$ events. On the regional scale, these results indicate that the onset of the widespread "mid-Langhian" flooding and installment of Badenian Sea may have occurred in some CP regions before $15 \mathrm{Ma}$. To render biostratigraphic data more reliable, provide firm constraints on the $\mathrm{CP}$ chronostratigraphy and precise timings of sea-level changes, more high-precision geochronology is required from individual CP basins.

Acknowledgements The work has been supported in part by Croatian Science Foundation under the project "Miocene syn-rift evolution of the North Croatian Basin (Carpathian-Pannonian Region): a multi-proxy approach, correlation and integration of sedimentary and volcanic record" (PYROSKA, HRZZ UIP-2019-04-7761). Katarína Holcová also acknowledges the support of the project PROGRES Q45 financed by Charles University (Prague). We would like to thank Dr. Andrea Di Capua for his very helpful comments and suggestions that improved the manuscript, as well as Professor Christoph Breitkreuz for editorial work. Additionally, thanks to Croatian Geological Survey Lab team, and Mirjana Miknić for field support.

Author contributions All authors contributed to the study conception and design. Material preparation, data collection, and analysis were performed by MB, SK, SG, KK, MB, VB, KH, KW, KB, VH, IM, MH, SS, and US. The first draft of the manuscript was written by MB and all authors commented on versions of the manuscript. All authors read and approved the final manuscript.

Funding The work has been supported in part by Croatian Science Foundation under the project "Miocene syn-rift evolution of the North Croatian Basin (Carpathian-Pannonian Region): a multi-proxy approach, correlation and integration of sedimentary and volcanic record" (PYROSKA, HRZZ UIP-2019-04-7761).

Availability of data and material All data generated or analyzed during this study are included in this article (and its supplementary information files).

\section{Compliance with ethical standards}

Conflict of interest The authors declare no conflicts of interest. 


\section{References}

Andersen NL, Jicha BR, Singer BS, Hildreth W (2017) Incremental heating of Bishop Tuff sanidine reveals preeruptive radiogenic $\mathrm{Ar}$ and rapid remobilization from cold storage. Proc Natl Acad Sci. https://doi.org/10.1073/pnas.1709581114

Bachmann O, Huber C (2016) Silicic magma reservoirs in the Earth's crust. Am Mineral 101:2377-2404

Balázs A, Matenco L, Magyar I, Horváth F, Cloething S (2016) The link between tectonics and sedimentation in back-arc basins: new genetic constraints from the analysis of the Pannonian Basin. Tectonics 35:1526-1559

Bowring JF, McLean NM, Bowring SA (2011) Engineering cyber infrastructure for $\mathrm{U}-\mathrm{Pb}$ geochronology: tripoli and $\mathrm{U}_{-} \mathrm{Pb}_{-}$ Redux. Geochem Geophys Geosyst 12:1-19

Branney MJ, Kokelaar P (2002) Pyroclastic density currents and the sedimentation of ignimbrites. Geological Society of London, London, p 15227

Brown RJ, Branney MJ (2004) Event-stratigraphy of a caldera-forming ignimbrite eruption on Tenerife: the 273-ka Poris Formation. Bull Volcanol 66:392-416

Brlek M, Iveša LJ, Brčić V, Santos A, Ćorić S, Milošević M, Avanić R, Devescovi M, Pezelj Đ, Mišur I, Miknić M (2018) Rockyshore unconformities marking the base of Badenian (Middle Miocene) transgressions on Mt. Medvednica basement (North Croatian Basin, Central Paratethys). Facies 64:25

Brown RJ, Andrews GDM (2015) Deposits of pyroclastic density currents. In: Sigurdsson H (ed) The encyclopedia of volcanoes, 2nd edn. Elsevier, Amsterdam, pp 631-648

Bull SW, Cas RAF (2000) Distinguishing base-surge deposits and volcaniclastic fluviatile sediments: an ancient example from the Lower Devonian Snowy River Volcanics, south-Eastern Australia. Sedimentology 47:87-98

Carey SN, Schneider J-L (2011) Volcaniclastic processes and deposits in the deep-sea. In: Hüneke H, Mulder T (eds) Deep-sea sediments. Developments in sedimentology. Elsevier, Amsterdam, pp 457-51563

Cas RAF, Wright JV (1988) Volcanic successions: modern and ancient. Chapmann \& Hall, London

Cassidy M, Watt SFL, Palmer MR, Trofimovs J, Symons W, Maclachlan SE, Stinton AJ (2014) Construction of volcanic records from marine sediment cores: a review and case study (Montserrat, West Indies). Earth Sci Rev 138:137-155

Condon DJ, Schoene B, McLean NM, Bowring SA, Parrish RR (2015) Metrology and traceability of $\mathrm{U}-\mathrm{Pb}$ isotope dilution geochronology (EARTHTIME Tracer Calibration Part I). Geochim Cosmochim Acta 164:464-480

Ćorić S, Pavelić D, Rögl F, Mandic O, Vrabac S, Avanić R, Jerković L, Vranjković A (2009) Revised Middle Miocene datum for initial marine flooding of North Croatian Basin (Pannonian Basin Systems, Central Paratethys). Geol Croat 62:31-43

Cvetković V, Poli G, Christofides G, Koroneos A, Pécskay Z, Resimić-Šarić K, Erić V (2007) The Miocene granitoid rocks of Mt. Bukulja (central Serbia): evidence for Pannonian extension-related granitoid magmatism in the northern Dinarides. Eur J Mineral 19:513-532

de Leeuw A, Mandic O, Vranjković A, Pavelić D, Harzhauser M, Krijgsman W, Kuiper KF (2010) Chronology and integrated stratigraphy of the Miocene Sinj Basin (Dinaride Lake System, Croatia). Palaoegeogr Palaeoclimatol Palaeoecol 292:155-167

de Leeuw A, Mandic O, Krijgsman W, Kuiper K, Hrvatović H (2012) Paleomagnetic and geochronological constraints on the geodynamic evolution of the Central Dinarides. Tectonophysics 530:286-298 de Leeuw A, Tulbure M, Kuiper KF, Melinte-Dobrinescu MC, Stoica M, Krijgsman W (2018) New ${ }^{40} \mathrm{Ar} /{ }^{39} \mathrm{Ar}$, magnetostratigraphic and biostratigraphic constraints on the termination of the Badenian Salinity Crisis: indications for tectonic improvement of basin interconnectivity in Southern Europe. Glob Planet Change $169: 1-15$

Di Capua A, Groppelli G (2016) Application of actualistic models to unravel primary volcanic control on sedimentation (Taveyanne Sandstones, Oligocene Northalpine Foreland Basin). Sediment Geol 336:147-160

Di Capua A, Groppelli G (2018) The riddle of volcaniclastic sedimentation in ancient deep-water basins: a discussion. Sediment Geol 378:52-60

Douillet GA, Taisne B, Tsang-Hin-Sun È, Müller SK, Kueppers U, Dingwell DB (2015) Syn-eruptive, soft-sediment deformation of deposits from dilute pyroclastic density current: triggers for granular shear, dynamic pore pressure, ballistic impact and shock waves. Solid Earth 6:553-572

Ellis BS, Schmitz MD, Hill M (2019) Reconstructing a Snake River Plain "super-eruption" via compositional fingerprinting and high-precision $\mathrm{U} / \mathrm{Pb}$ zircon geochronology. Contrib Mineral Petrol 174:101

Fodor LI, Gerdes A, Dunkl I, Koroknai B, Pécskay Z, Trajanova M, Horváth P, Vrabec M, Jelen B, Balogh K, Frisch W (2008) Miocene emplacement and rapid cooling of the Pohorje pluton at the Alpine-Pannonian-Dinaridic junction, Slovenia. Swiss J Geosci 101:255-271

Fodor LI, Márton E, Ma V, Koronkai B, Trajanova M, Mi V (2020) Relationship between magnetic fabrics and deformation of the Miocene Pohorje intrusions and surrounding sediments (Eastern Alps). Int J Earth Sci. https://doi.org/10.1007/s00531-020-01846 $-4$

Gaynor SP, Rosera JM, Coleman DS (2019) Intrusive history of the Oligocene Questa porphyry molybdenum deposit, New Mexico. Geosphere 15:548-575

GKRH (2009) Geološka karta Republike Hrvatske (Geological Map of the Republic of Croatia) scale 1:300.000. Hrvatski geološki institut (Croatian Geological Survey), Zagreb, 1 sheet

Gorton MP, Schandl ES (2000) From continents to island arcs: a geochemical index of tectonic setting for arc-related and within-plate felsic to intermediate volcanic rocks. Can Mineral 38:1065-1073

Gradstein FM, Ogg JG, Schmitz MD, Ogg GM (2012) The Geologic Time Scale 2012. Elsevier, Oxford

Gubler T (2009) Blatt 1111 Albis (mit Beitrag von P. Nagy). Geol. Atlas Schweiz 1:25.000, Erläut: 134. Bundesamt für Landestopographie swisstopo

Günther D, Jackson SE, Longerich HP (1999) Laser ablation and arc/ spark solid sample introduction into inductively coupled plasma mass spectrometers. Spectrochim Acta Part B 54:381-409

Hajek-Tadesse V, Belak M, Sremac J, Vrsaljko D, Wacha L (2009) Early Miocene ostracods from the Sadovi section (Mt Požeška gora, Croatia). Geol Carpath 60:251-262

Halamić J, Belak M, Pavelić D, Avanić R, Filjak R, Šparica M, Brkić M, Kovačić M, Vrsaljko D, Banak A, Crnko J (2019) Basic geological map 1:50.000. Sheet Požeška gora. Croatian Geological Survey, Zagreb

Handler R, Ebner F, Neubauer F, Bojar A-V, Hermann S (2006) ${ }^{40} \mathrm{Ar} /{ }^{39} \mathrm{Ar}$ dating of Miocene tuffs from the Styrian part of the Pannonian Basin: an attempt to refine the basin stratigraphy. Geol Carpath 57:483-494

Handy MR, Ustaszewski K, Kissling E (2014) Reconstructing the Alps-Carpathians-Dinarides as a key to understanding switches in subduction polarity, slab gaps and surface motion. Int J Earth Sci (Geol Rundsch) 104:1-26

Harangi S, Lenkey L (2007) Genesis of the Neogene to Quaternary volcanism in the Carpathian-Pannonian region: role of subduction, 
extension, and mantle plume. In: Beccaluva L, Bianchini G, Wilson M (eds) Cenozoic volcanism in the Mediterranean Area. Geological Society of America, Boulder, pp 67-92418

Harangi S, Mason PRD, Lukács R (2005) Correlation and petrogenesis of silicic pyroclastic rocks in the Northern Pannonian Basin, Eastern-Central Europe: in situ trace element data of glass shards and mineral chemical constraints. J Volcanol Geotherm Res 143:237-257

Harangi S, Downes H, Thirlwall M, Gméling K (2007) Geochemistry, petrogenesis and geodynamic relationships of Miocene calcalkaline volcanic rocks in the Western Carpathian Arc, Eastern Central Europe. J Petrol 48:2261-2287

Hernitz Kučenjak M, Premec Fućek V, Krizmanić K, Tadej J, Zlatar S, Matošević M (2018) Karpatian and Badenian transgressions in Croatian part of the Pannonian Basin System (biostratigraphy and palaeoenvironments). Forams 2018. Temporary Abstract Collection, Edinburgh, pp 273-274

Hiess J, Condon DJ, McLean N, Noble SR (2012) ${ }^{238} U /{ }^{235}$ U systematics in terrestrial uranium-bearing minerals. Science 335:1610-1614

Hildreth W, Firestein J (2012) The Novarupta-Katmai eruption of 1912-largest eruption of the twentieth century: centennial perspectives. US Geological Survey Professional Paper 1791, p 259

Hilgen FJ, Lourens LJ, Van Dam JA (2012) The Neogene period. In: Gradstein FM, Ogg JG, Schmitz MD, Ogg GM (eds) The Geological Time Scale 2012. Elsevier, Amsterdam, pp 923-978

Hohenegger J, Ćorić S, Wagreich M (2014) Timing of the Middle Miocene Badenian stage of the Central Paratethys. Geol Carpath 65:55-66

Holcová K, Dolákova N, Nehyba S, Vacek F (2018) Timing of Langhian bioevents in the Carpathian Foredeep and northern Pannonian Basin in relation to oceanographic, tectonic and climatic processes. Geol Q 62:3-17

Hopkins JL, Seward D (2019) Towards robust tephra correlations in early and pre-Quaternary sediments: a case study from North Island, New Zealand. Q Geochronol 50:91-108

Horváth F, Bada G, Szafián P, Tari G, Ádám A, Cloetingh S (2006) Formation and deformation of the Pannonian Basin: constraints from observational data. In: Gee DG, Stephenson RA (eds) European lithosphere dynamics. Geological Society, London, pp 191-20632

Horváth F, Musitz B, Balázs A, Végh A, Uhrin A, Nádor A, Koroknai B, Pap N, Tóth T, Wórum G (2015) Evolution of the Pannonian Basin and its geothermal resources. Geothermics 53:328-352

Hudspith VA, Scott AC, Wilson CJN, Collinson ME (2010) Charring of woods by volcanic processes: an example from the Taupo ignimbrite, New Zealand. Palaeogeogr Palaeoclimatol Palaeoecol 292:35-43

Ji W-Q, Malusà MG, Tiepolo M, Langone A, Zhao L, Wu F-Y (2019) Synchronous Periadriatic magmatism in the Western and Central Alps in the absence of slab breakoff. Terra Nova 31:120-128

Kästle ED, Rosenberg C, Boschi L, Bellahansen N, Meier T, ElSharkawy A (2020) Slab break-offs in the Alpine subduction zone. Int J Earth Sci 109:587-603

Kataoka KS, Manville V, Nakajo T, Urabe A (2009) Impacts of explosive volcanism on distal alluvial sedimentation: examples from the Pliocene-Holocene volcaniclastic successions of Japan. Sediment Geol 220:306-317

Koppers AAP (2002) ArArCALC F software for ${ }^{40} \mathrm{Ar} /{ }^{39} \mathrm{Ar}$ age calculations. Comput Geosci 28:605-619

Koroneos A, Poli G, Cvetković V, Christofides G, Krstić D, Pécskay Z (2010) Petrogenetic and tectonic inferences from the study of the Mt Cer pluton (West Serbia). Geol Mag 148:89-111

Kováč M, Halásova E, Hudáčkova N, Holcová K, Hyžný M, Jamrich M, Ruman A (2018) Towards better correlation of the Central Paratethys regional time scale with the standard geological time scale of the Miocene Epoch. Geol Carpath 69:283-300
Kovačić M, Pavelić D (2017) Neogene stratigraphy of Slavonian Mountains. In: Kovačić M, Wacha L, Horvat M (eds) Field trip guidebook: Neogene of Central and South-Eastern Europe. Croatian Geological Society, Zagreb, pp 5-9

Krogh TE (1973) A low-contamination method for hydrothermal decomposition of zircon and extraction of $\mathrm{U}$ and $\mathrm{Pb}$ for isotopic age determinations. Geochim Cosmochim Acta 37:485-494

Kuiper K, Deino A, Hilgen FJ, Krijgsman W, Renne PR, Wijbrans JR (2008) Synchronizing rock clocks of Earth history. Science 320:500-504

Kutterolf S, Freundt A, Burkert C (2011) Eruptive history and magmatic evolution of the $1.9 \mathrm{kyr}$ Plinian dacitic Chiltepe Tephra from Apoyegue volcano in west-central Nicaragua. Bull Volcanol 73:811-831

Kutterolf S, Schindlbeck JC, Scudder RP, Murray RW, Pickering KT, Freundt A, Labanieh S, Heydolph K, Saito S, Naruse H, Underwood MB, Wu H (2014) Large volume submarine ignimbrites in the Shikoku Basin: an example for explosive volcanism in the Western Pacific during the Late Miocene. Geochem Geophys Geosyst 15:1837-1851

Kutterolf S, Schindlbeck JC, Robertson AHF, Avery A, Baxter AT, Petronotis K, Wang K-L (2018) Tephrostratigraphy and provenanace from IODP expedition 352, Izu-Bonin Arc: tracing tephra sources and volumes from the Oligocene to recent. Geochem Geophys Geosyst 19:150-174

Lee JY, Marti K, Severinghaus JP, Kawamura K, Yoo HS, Lee JB, Kim JS (2006) A redetermination of the isotopic abundances of atmospheric Ar. Geochim Cosmochim Acta 70:4507-4512

Lowe DR (1975) Water escape structures in coarse-grained sediments. Sedimentology 22:157-204

Lowe DJ (2011) Tephrochronology and its application: a review. Q Geochronol 6:107-153

Lowe DJ, Pearce NJG, Jorgensen MA, Kuehn SC, Tryon CA, Hayward CL (2017) Correlating tephras and cryptotephras using glass compositional analyses and numerical and statistical methods: review and evaluation. Q Sci Rev 175:1-44

Lukács R, Harangi S, Bachmann O, Guillong M, Danišík M, Buret Y, von Quadt A, Dunkl I, Fodor L, Sliwinski J, Soós I, Szepesi J (2015) Zircon geochronology and geochemistry to constrain the youngest eruption events and magma evolution of the MidMiocene ignimbrite flare-up in the Pannonian Basin, eastern central Europe. Contrib Mineral Petrol 170:52

Lukács R, Harangi S, Guillong M, Bachmann O, Fodor L, Buret Y, Dunk1 I, Sliwinski J, von Quadt A, Peytcheva I, Zimmerer M (2018) Early to Mid-Miocene syn-extensional massive silicic volcanism in the Pannonian Basin (East-Central Europe): eruption chronology, correlation potential and geodynamic implications. Earth Sci Rev 179:1-19

Mandic O, de Leeuw A, Vuković B, Krijgsman W, Harzhauser M, Kuiper KF (2011) Palaeoenvironmental evolution of Lake Gacko (Bosnia and Herzegovina): impact of the middle Miocene climatic optimum on on the Dinaride Lake System. Palaoegeogr Palaeoclimatol Palaeoecol 299:475-492

Mandic O, de Leeuw A, Bulić J, Kuiper KF, Krijgsman W, JurišićPolšak Z (2012) Paleogeographic evolution of the Southern Pannonian Basin: ${ }^{40} \mathrm{Ar} /{ }^{39} \mathrm{Ar}$ age constraints on the Miocene continental series of Northern Croatia. Int J Earth Sci 101:1033-1046

Mandic O, Hajek-Tadesse V, Bakrač K, Reichenbacher B, Grizelj A, Miknić M (2019a) Multiproxy reconstruction of the middle Miocene Požega paleolake in the Southern Pannonian Basin (NE Croatia) prior to the Badenian transgression of the Central Paratethys Sea. Palaoegeogr Palaeoclimatol Palaeoecol 516:203-219

Mandic O, Sant K, Kallanxhi M-E, Ćorić S, Theobalt D, Grunert P, de Leeuw A, Krijgsman W (2019b) Integrated bio-magnetostratigraphy of the Badenian reference section Ugljevik 
in southern Pannonian Basin-implications for the Paratethys history (middle Miocene, Central Europe). Glob Planet Change 172:374-395

Mandic O, Lj R, Ćorić S, Pezelj Đ, Theobalt D, Sant K, Krijgsman W (2019c) Age and mode of the Middle Miocene marine flooding of the Pannonian Basin—constraints from central Serbia. Palaios 34:71-95

Marković F (2017) Miocene tuffs of the North Croatian Basin. Dissertation, University of Zagreb

Matenco L, Radivojević D (2012) On the formation and evolution of the Pannonian Basin: constraints derived from the structure of the junction area between the Carpathians and Dinarides. Tectonics 31:TC6007

Mattinson JM (2005) Zircon U-Pb chemical abrasion ("CA-TIMS") method: combined annealing and multi-step partial dissolution analysis for improved precision and accuracy of zircon ages. Chem Geol 220:47-66

McDonough WF, Sun S-S (1995) The composition of the Earth. Chem Geol 120:223-253

McLean NM, Bowring JF, Bowring SA (2011) An algorithm for U$\mathrm{Pb}$ isotope dilution data reduction and uncertainty propagation. Geochem Geophys Geosyst 12:QOAA18

McLean NM, Condon DJ, Schoene B, Bowring SA (2015) Evaluating uncertainties in the calibration of isotopic reference materials and multi-element isotopic tracers (EARTHTIME Tracer Calibration Part II). Geochim Cosmochim Acta 164:481-501

McPhie J, Doyle M, Allen R (1993) Volcanic textures: a guide to the interpretation of textures in volcanic rocks. CODES Key Centre, Hobart

Miller W III (2006) Trace fossils: concepts, problems, prospects. Elsevier, Amsterdam

Min K, Mundil R, Renne PR, Ludwig KR (2000) A test for systematic errors in ${ }^{40} \mathrm{Ar} /{ }^{39} \mathrm{Ar}$ geochronology through comparison with $\mathrm{U} / \mathrm{Pb}$ analysis of a 1.1-Ga rhyolite. Geochim Cosmochim Acta 64:73-98

Mundil R, Ludwig KR, Metcalf I, Renne PR (2004) Age and timing of the Permian max extinctions: U/Pb dating and closed-system zircons. Science 305:669-673

Neubauer F, Heberer B, Dunkl I, Liu X, Bernroider M, Dong Y (2018) The Oligocene Reifnitz tonalite (Austria) and its host rocks: implications for Cretaceous and Oligocene-Neogene tectonics of the south-eastern Eastern Alps. Geol Carpath 69:237-253

Ovtcharova M, Goudemand N, Hammer O, Gudoun K, Cordey F, Galfetti T, Schaltegger U, Bucher H (2015) Developing a strategy for accurate definition of a geological boundary through radioisotope and biochronological dating: the Early-Middle Triassic boundary (South China). Earth Sci Rev 146:65-76

Owen G, Moretti M, Alfaro P (2011) Recognising triggers for softsediment deformation: current understanding and future directions. Sediment Geol 235:133-140

Pamić J, Balen D (2001a) Tertiary magmatism of the Dinarides and the adjoining South Pannonian Basin: an overview. Acta Vulcanol 13:9-24

Pamić J, Balen D (2001b) Petrology and geochemistry of EgerianEggenburgian and Badenian tholeiite-calc-alkaline volcanics from the South Pannonian Basin (Croatia). N Jb Minerol Abh 176:237-267

Pamić J, McKee EH, Bullen TD, Lanphere MA (1995) Tertiary volcanic rocks from the Southern Pannonian Basin, Croatia. Int Geol Rev 37:259-283

Pavelić D (2001) Tectonostratigraphic model for the North Croatian and North Bosnian sector of the Miocene Pannonian Basin System. Basin Res 13:359-376

Pavelić D, Kovačić M (2018) Sedimentology and stratigraphy of the Neogene rift-type North Croatian Basin (Pannonian Basin System, Croatia): a review. Mar Pet Geol 91:455-469
Pavelić D, Avanić R, Bakrač K, Vrsaljko D (2001) Early Miocene braided river and lacustrine sedimentation in the Kalnik mountain area (Pannonian Basin System, NW Croatia). Geol Carpath 52:375-386

Peccerillo A, Taylor SR (1976) Geochemistry of Eocene calc-alkaline volcanic rocks from the Kastamonuarea, northern Turkey. Contrib Minerol Petrol 58:63-71

Pécskay Z, Lexa J, Szakács A, Seghedi I, Balogh K, Konečný V, Zelenka T, Kovacs M, Póka T, Fülöp A, Márton E, Panaiotu C, Cvetković V (2006) Geochronology of Neogene magmatism in the Carpathian arc and intra-Carpathian area. Geol Carpath 57:511-530

Phillips D, Matchan EL (2013) Ultra-high precision ${ }^{40} \mathrm{Ar} /{ }^{39} \mathrm{Ar}$ ages for Fish Canyon Tuff and Alder Creek Rhyolite sanidine: new dating standards required? Geochim Cosmochim Acta 121:229-239

Poli G, Christofides G, Koroneos A, Trajanova M, Zupančić N (2020) Multiple processes in the genesis of the Pohorje igneous complex: evidence from petrology and geochemistry. Lithos. https:// doi.org/10.1016/j.lithos.2020.105512

Reiners PW, Carlson RW, Renne PR, Cooper KM, Granger DE, McLean NM, Schoene B (2018) Geochronology and thermochronology. Wiley, Hoboken

Rivera T, Storey M, Schmitz M, Crowley JL (2013) Age intercalibration of ${ }^{40} \mathrm{Ar} /{ }^{39} \mathrm{Ar}$ sanidine and chemically distinct $\mathrm{U} / \mathrm{Pb}$ zircon populations from the Elder Creek Rhyolite Quaternary geochronology standard. Chem Geol 345:87-98

Rocholl A, Schaltegger U, Gilg HA, Wijbrans J, Böhme M (2018) The age of volcanic tuffs from the Upper Freshwater Molasse (North Alpine Foreland Basin) and their possible use for tephrostratigraphic correlations across Europe for the Middle Miocene. Int J Earth Sci (Geol Rundsch) 107:387-407

Rögl F (1998) Paleogeographic considerations for Mediterranean and Paratethys seaways (Oligocene to Miocene). Ann Naturhist Mus Wien 99:279-310

Rosenberg CL (2004) Shear zones and magma ascent: a model based on a review of the tertiary magmatism in the Alps. Tectonics 23:TC3002

Rybár S, Šarinová K, Sant K, Kuiper KF, Kováčová M, Vojtko R, Resiser MK, Fordinál K, Theodoridis V, Nováková P, Vlček T (2019) New ${ }^{40} \mathrm{Ar} /{ }^{39} \mathrm{Ar}$, fission track and sedimentological data on a middle Miocene tuff occurring in the Vienna Basin: implications for the north-western Central Paratethys region. Geol Carpath 70:386-404

Sahy D, Condon DJ, Hilgen FJ, Kuiper KF (2017) Reducing disparity in radio-isotopic and astrochronology-based time scales of the Late Eocene and Oligocene. Paleoeceanography 32:1018-1035

Samperton KM, Schoene B, Cottle JM, Keller CB, Crowley JL, Schmitz MD (2015) Magma emplacement, differentiation and cooling in the middle crust: integrated zircon geochronologicalgeochemical constraints from the Bergell intrusion, Central Alps. Chem Geol 417:322-340

Sant K, Palcu D, Mandic O, Krijgsman W (2017) Changing seas in the Early-Middle Miocene of Central Europe: a Mediterranean approach to Paratethyan stratigraphy. Terra Nova 29:273-281

Sant K, Palcu DV, Turco E, Di Stefano A, Baldassini N, Kouwenhoven T, Kuiper KF, Krijgsman W (2019) The mid-Langhian flooding in the eastern Central Paratethys: integrated stratigraphic data from the Transylvanian Basin and SE Carpathian Foredeep. J Earth Sci 108:2209-2232

Sant K, Kuiper KF, Rybár S, Grunert P, Harzhauser M, Mandic O, Jamrich M, Šarinová K, Hudáčková N, Krijgsman W (2020) ${ }^{40} \mathrm{Ar} /{ }^{39} \mathrm{Ar}$ geochronology using high sensitivity mass spectrometry: examples from middle Miocene horizons of the Central Paratethys. Geol Carpath 71:166-182

Schaltegger U, Brack P, Ovtcharova M, Peytcheva I, Schoene B, Stracke A, Marocchi M, Bargossi GM (2009) Zircon and titanite 
recording 1.5 million years of magma accretion, crystallization and initial cooling in a composite pluton (southern Adamello batholith, northern Italy). Earth Planet Sci Lett 286:208-218

Schaltegger U, Schmitt AK, Horstwood MSA (2015) U-Th-Pb zircon geochronology by ID-TIMS, SIMS and laser ablation ICPMS: recipes, interpretations, and opportunities. Chem Geol 402:89-110

Schefer S, Cvetković V, Fügenschuh B, Kounov A, Ovtcharova M, Schaltegger U, Schmid SM (2011) Cenozoic granitoids in the Dinarides of southern Serbia: age of intrusion, isotope geochemistry, exhumation history and significance for the geodynamic evolution of the Balkan Peninsula. Int J Earth Sci (Geol Rundsch) 100:1181-1206

Schindlbeck JC, Kutterolf S, Freundt A, Scudder RP, Pickering KT, Murray RW (2013) Emplacement processes of submarine volcaniclastic deposits (IODP Site C0011, Nankai Trough). Mar Geol 343:115-124

Schindlbeck JC, Kutterolf S, Freundt A, Alvarado GE, Wang K-L, Straub SM, Hemming SR, Frische M, Woodhead JD (2016) Late Cenozoic tephrostratigraphy offshore the southern Central American Volcanic Arc: 1. Tephra ages and provenance. Geochem Geophys Geosyst 17:4641-4668

Schindlbeck JC, Kutterolf S, Freundt A, Eisele S, Wang K-L, Frische M (2018) Miocene to Holocene marine tephrostratigraphy offshore northern Central America and southern Mexico: pulsed activity of known volcanic complexes. Geochem Geophys Geosyst 19:4143-4173

Schmid SM, Bernoulli D, Fügenschuh B, Matenco L, Schefer S, Schuster R, Tischler M, Ustaszewski K (2008) The Alpine-Carpathian-Dinaridic orogenic system: correlation and evolution of tectonic units. Swiss J Geosci 101:139-183

Schmitz MD (2012) Radiogenic isotope geochronology. In: Gradstein FM, Ogg JG, Schmitz MD, Ogg GM (eds) The Geological Time Scale 2012. Elsevier, Amsterdam, pp 115-126

Schmitz MD (2018) Geologic Time Scale. In: White WM (ed) Encyclopedia of geochemistry. Springer, Berlin, pp 586-589

Schmitz MD, Kuiper KF (2013) High-precision geochronology. Elements 9:25-30

Schneider J-L, Le Ruyet A, Chanier F, Buret C, Ferrière J, Proust J-N, Rosseel J-B (2001) Primary or secondary distal volcaniclastic turbidites? An example from the Miocene of New Zealand (Mahia Peninsula, North Island). Sediment Geol 145:1-22

Seghedi I, Downes H (2011) Geochemistry and tectonic development of Cenozoic magmatism in the Carpathian-Pannonian region. Gondwana Res 20:655-672

Shanmugam G (2017) Global case studies of soft-sediment deformation structures (SSDS): definitions, classifications, advances, origins, and problems. J Palaeogeogr 6:251-320

Söderlund U, Johansson L (2002) A simple way to extract baddeleyite $\left(\mathrm{ZrO}_{2}\right)$. Geochem Geophys Geosyst 3:1-7

Stoppa L, Kutterolf S, Rausch J, Grobety B, Pettke T, Wang K-L, Hemming S (2018) The Malpaisillo Formation: a sequence of explosive eruptions in the mid to late Pleistocene (Nicaragua, Central America). J Volcanol Geotherm Res 359:47-67

Strasky S, Schaltegger U, Ovtcharova M, Hofmann B, Kälin D (2018) Age determination and correlation of the Wolhusen Bentonite (Upper Freshwater Molasse, Middle Miocene, Napf alluvial fan, Switzerland). In: Dèzes P (ed) Abstract Volume: 16th Swiss Geoscience Meeting. Universität Bern, p 204

Sun S, McDonough WF (1989) Chemical and isotopic systematics of oceanic basalts: implications for mantle composition and processes. In: Sauders SJ, Norry MJ (eds) Magmatism in the ocean basins. Geological Society London Special Publications, London, pp 313-345

Szakács A, Pécskay Z, Gál Á (2018) Patterns and trends of time-space evolution of Neogene volcanism in the Carpathian-Pannonian region: a review. Acta Geod Geophys 53:347-367

Szymanowski D, Ellis BS, Wotzlaw JF, Buret Y, von Quadt A, Peytcheva I, Bindeman IN, Bachmann O (2016) Geochronological and isotopic records of crustal storage and assimilation in the Wolverine Creek-Conant Creek system, Heise eruptive centre, Snake River Plain. Contrib Mineral Petrol 171:106

Szymanowski D, Ellis BS, Wotzlaw J-F, Bachmann O (2019) Maturation and rejuvenation of a silicic magma reservoir: high-resolution chronology of the Kneeling Nun Tuff. Earth Planet Sci Lett 510:103-115

Šegvić B, Mileusnić M, Aljinović D, Vranjković A, Mandic O, Pavelić D, Dragičević I, Mählmann RF (2014) Magmatic provenance and diagenesis of Miocene tuffs from the Dinaride Lake System (the Sinj Basin, Croatia). Eur J Mineral 26:83-101

Šimunić A, Hećimović I, Avanić R (2013) Basic geological map 1:100,000. Sheet Koprivnica. Croatian Geological Survey, Zagreb

Šimunić A, Hećimović I, Avanić R (2014) Basic geological map 1:100,000. Sheet Koprivnica, explanatory notes. Zagreb, Croatian Geological Survey, p 94

Tibljaš D, Loparić V, Belak M (2002) Discriminant function analysis of Miocene volcaniclastic rocks from north-western Croatia based on geochemical data. Geol Croat 55:39-44

Trofimovs J, Sparks RSJ, Talling PJ (2008) Anatomy of a submarine pyroclastic flow and associated turbidity current: July 2003 dome collapse, Soufrière Hills volcano, Montserrat, West Indies. Sedimentology 55:617-634

van Loon AJ (2009) Soft-sediment deformation structures in siliciclastic sediments: an overview. Geologos 15:3-55

Vervoort J (2018) Geochronology and radiogenic isotopes. In: White WM (ed) Encyclopedia of geochemistry. Springer, Berlin, pp 571-586

von Quadt A, Erni M, Marinek K, Moll M, Peytcheva I, Heinrich CA (2011) Zircon crystallization and the lifetimes of ore-forming magmatic-hydrothermal systems. Geology 39:731-734

White JDL, Houghton BF (2006) Primary volcaniclastic rocks. Geology 34:677-680

Widmann P, Davies JHFL, Schaltegger U (2019) Calibrating chemical abrasion: its effects on zircon crystal structure, chemical composition and $\mathrm{U}-\mathrm{Pb}$ age. Chem Geol 511:1-10

Wilson CJN, Houghton BF, Kamp PJJ, McWilliams MO (1995) An exceptionally widespread ignimbrite with implications for pyroclastic flow emplacement. Nature 378:605-607

Wotzlaw J-F, Schaltegger U, Frick DA, Dungan MA, Gerdes A, Günther D (2013) Tracking the evolution of large-volume silicic magma reservoirs from assembly to supereruption. Geology $41: 867-870$

Wotzlaw J-F, Hüsing SK, Hilgen FJ, Schaltegger U (2014) Highprecision zircon $\mathrm{U}-\mathrm{Pb}$ geochronology of astronomically dated volcanic ash beds from the Mediterranean Miocene. Earth Planet Sci Lett 407:19-34

Wotzlaw J-F, Brack P, Storck J-C (2018) High-resolution stratigraphy and $\mathrm{U}-\mathrm{Pb}$ geochronology of the Middle Triassic Buchenstein Formation (Dolomites, northern Italy): precession-forcing of hemipelagic carbonate sedimentation and calibration of the Anisian-Ladinian boundary interval. J Geol Soc 175:71-85 


\section{Affiliations}

Mihovil Brlek ${ }^{1}$ D $\cdot$ Steffen Kutterolf ${ }^{2} \cdot$ Sean Gaynor $^{3} \cdot$ Klaudia Kuiper $^{4} \cdot$ Mirko Belak $^{1} \cdot$ Vlatko Brčić $^{1}$.

Katarína Holcová ${ }^{5}$ Kuo-Lung Wang ${ }^{6,7}$ • Koraljka Bakrač ${ }^{1}$ - Valentina Hajek-Tadesse ${ }^{1}$. Ivan Mišur ${ }^{1}$. Marija Horvat ${ }^{1}$. Sanja Šuica ${ }^{8} \cdot$ Urs Schaltegger $^{3}$

1 Department of Geology, Croatian Geological Survey, Sachsova 2, 10000 Zagreb, Croatia

2 GEOMAR Helmholtz Center for Ocean Research Kiel, FB4, Dynamics of the Ocean Floor, Wischhofstrasse 1-3, 24148 Kiel, Germany

3 Department of Earth Sciences, University of Geneva, Rue des Maraichers 13, 1205 Geneva, Switzerland

4 Department of Earth Sciences, Vrije Universiteit Amsterdam, Faculty of Science, De Boelelaan 1085, 1081 HV Amsterdam, The Netherlands
Institute of Geology and Palaeontology, Charles University, Albertov 6, 12843 Prague 2, Czech Republic

6 Institute of Earth Sciences, Academia Sinica, 128 Academia Road Sec. 2, Nangang, Taipei 115, Taiwan

7 Department of Geosciences, National Taiwan University, No. 1, Sec. 4, Roosevelt Rd, Taipei 10617, Taiwan

8 Rock and Fluid Analysis, INA-Industrija Nafte, D.D., Lovinčićeva 4, 10000 Zagreb, Croatia 